Article

\title{
Social Sustainability in Apparel Supply Chains-The Role of the Sourcing Intermediary in a Developing Country
}

\author{
Deniz Köksal ${ }^{1, *}$, Jochen Strähle ${ }^{1}$ and Martin Müller ${ }^{2}$ \\ 1 School of Textiles \& Design, Reutlingen University, Alteburgstraße 150, 72762 Reutlingen, Germany; \\ jochen.straehle@reutlingen-university.de \\ 2 Institute of Sustainable Corporate Management, Ulm University, Helmholtzstraße 18, 89081 Ulm, Germany; \\ martin.mueller@uni-ulm.de \\ * Correspondence: deniz.koeksal@reutlingen-university.de
}

Received: 23 February 2018; Accepted: 28 March 2018; Published: 31 March 2018

\begin{abstract}
After considering significant literature on sustainable supply chain management (SSCM), it is evident that research has neglected the social dimension and still lacks in highlighting the role of sourcing intermediaries in supply chains. The apparel supply chain has increased enormously in length and complexity, driving apparel retailers to employ sourcing intermediaries who manage their sourcing activities with suppliers from developing countries overseas. Thus, the purpose of this study is to enrich existing findings on SSCM by exploring the management of social sustainability when sourcing intermediaries are in between the focal company and the respective developing country factories. More specifically, this study aims to understand the role of apparel sourcing intermediaries for the implementation of social management strategies based on the perception of multiple supply chain actors. Qualitative data was collected through semi-structured interviews conducted in Vietnam and Europe. Ultimately ten propositions are presented, all explicitly concentrating on the apparel intermediary's role as a significant enabler for social sustainability in apparel supply chains. The roles are social sustainability, supplier developer and coordinator, gatekeeper and safeguard, cultural broker, and social risk manager. The social sustainability roles assumed by the apparel sourcing intermediary offer great opportunities to both apparel retailers and developing country factories.
\end{abstract}

Keywords: SSCM; supply chain management; sourcing intermediary; social sustainability; apparel/clothing industry; developing country; suppliers

\section{Introduction}

Today's apparel consumers expect constant change and new products have to be available on a frequent basis. These facts lead to increased pressure on apparel retailers to achieve lower costs and shorter lead times [1]. Therefore the apparel industry has faced a dramatic shift as western apparel retailers began to source their products increasingly from developing countries who offered a competitive advantage with lower labor costs [2,3]. In other words, with its global reach and as competitive pressures increase, the shift to low-cost developing country suppliers [1,4-7] leads to increasingly complex, globally dispersed and highly dynamic apparel supply chains $[2,6,8-16]$ and emphasizes the focus on sustainability. This race to the bottom typically results in a contradiction to the concept of sustainability, defined as the "development that meets the needs of the present without compromising the ability of future generations to meet their own needs" by the Brundtland Report of the World Commission on Environment and Development (WCED) [17]. It becomes specifically clear when considering the definition stated by The European Commission that CSR (Corporate Social Responsibility) is "the responsibility of enterprises for their impacts on society" [18]. The literature on 
the social dimension in SSCM (sustainable supply chain management) has developed over the last few years, but still remains an insufficiently explored field [19]. Indeed, during the TBL (Triple Bottom Line) debate $[20,21]$, the environmental dimension came to the forefront and gained much attention by academics $[16,22]$. This becomes clear by screening significant literature reviews on sustainable supply chain management. In fact, the environmental dimension appears to be predominantly researched, including current research trends in sustainable green supply chain management [23], energy efficiency and environmental sustainability initiatives [24], and circular economies [25]. Although there is rising concern toward social issues, the ongoing lack has been underlined explicitly by the latest reviews on social SSCM [26-28]. This shortcoming calls for socially related research, especially in the apparel industry. The nature of the buyer-driven apparel industry has been described by academics [14,29-32] and observe that is characterized by downward price pressures, negative buying practices with regard to costs, speed and flexibility, and supply chain complexity $[1,5,10,14,31,33]$. It is agreed that these attributes cause social issues throughout the supply chain [12,14,26,29,33-38]. In fact, many risks have been detected, contributing to forlorn social situations in the apparel supply chain that lead to poor working conditions such as sweatshops [39,40], child labor [34,41,42], and even factory collapses like the Rana Plaza building in Bangladesh [39,40,43-49]. Therefore, apparel retailers are increasingly in the spotlight and the subject of harsh media criticism and are under growing pressure from external stakeholders like consumers, governments, and NGOs [12,16,26,38,49]. As a consequence, apparel retailers implement social management strategies $[26,27,49]$ in order to tackle social issues in their supply chain and to respond to and mitigate external risks [12,16], especially when the unfavorable publicity will cause lasting damage to the apparel brand [44,46,48,50].

In general, apparel retailers have two basic options for sourcing products from developing countries i.e., direct sourcing, mediated sourcing, or a combination of both [51]. In fact, these circumstances pushed apparel intermediaries into the foreground, facilitating the management of globally dispersed value chains that generate remarkable competitive advantages for apparel retailers to achieve the best prices, quality, and lead times possible $[15,51-56]$. Nonetheless, independent sourcing intermediaries are another actor in the apparel supply chain $[15,52,55]$ and researchers point out the increasing difficulties in implementing sustainable supply chain management strategies the longer a supply chain becomes [14,57]. Consequently, the need to understand how to integrate social sustainability with globally fragmented supply chains is a critical task $[12,26,28]$. Specific questions arise, such as how apparel retailers control and perform social management strategies [26-28,49] once independent sourcing intermediaries exist in between the factory and the focal company. Moreover, to the best of the authors' knowledge, this study is the first of its kind to explore the role of the sourcing intermediary for the implementation of social sustainability to the apparel supply chain based on the view from three supply chain actors i.e., the apparel retailer, sourcing intermediary, and factories. To date no other study was found investigating the apparel supply chain with an exclusive focus on the intermediary and its role for social sustainability, thus contributing to the SSCM debate with novel, inductive findings to trigger socially related research in sustainable supply chain management and open new avenues of research.

Accordingly, this study attempts to extend existing sustainable supply chain frameworks with new insights and viewpoints while tackling the ongoing lack and widely neglected area regarding the investigation of apparel intermediaries, social sustainability, and research in developing countries. Ultimately this leads to the question of why and how are Vietnamese apparel suppliers sourcing intermediaries and how are the factories tackling social issues? How do apparel supply chain actors perceive the role of the apparel sourcing intermediary for the implementation of social management strategies?

By conducting semi-structured interviews with an apparel sourcing intermediary, one of its customers (a western apparel retailer), and four of its respective suppliers, the authors contribute to both academic and professional discourse. Thus, the paper at hand learns from industry professionals and extends existing conceptual models on socially related SSCM with a new actor, the sourcing 
intermediary. Furthermore, this study offers valuable managerial guidelines by highlighting the importance of the social dimension in apparel supply chains and gives valuable advice on the effective management of the CSR practices of an apparel company.

The second section provides a brief summary of recent SSCM related literature reviews, including the presentation of a theoretical framework and the characteristics of the apparel industry to justify the study at hand and thus its guiding research questions. The third section describes the methodology used to explore the research questions and presents the companies used as case studies. In Section 4 the results are presented. In Section 5 key research findings are discussed by outlining ten propositions. Finally, this paper ends with conclusions that include both academic as well as managerial implications.

\section{Literature Review}

\subsection{Management of Social Sustainability in Apparel Supply Chains}

As outlined in the introduction, the latest literature reviews reveal that the social dimension of the TBL still lag behind environmental considerations [22]. Nevertheless, recent review papers on social supply chain management $[19,26-28]$ can be viewed as substantial starting points to trigger socially related research, offering theoretical and conceptual frameworks that point at specific research gaps.

Köksal et al. [26] reviewed papers that specifically dealt with the textile/apparel industry and offered a beneficial conceptual framework to understand related drivers, enablers, and barriers for the implementation of social risk management practices in textile/apparel supply chains. While social risk management practices include collaboration and assessment (see also [58]), and reporting on the activities of a focal company, they also help to mitigate external risks and stakeholder pressures such as negative press in the media and improve social performance in the supply chain [26]. Yawar \& Seuring [27] classify responsible supply chain actions with three underlying strategies: communication, compliance, and supplier development. By considering all three actors of SSCM, their findings clearly emphasize the importance of a company's internal orientation towards sustainability (both, focal company, or supplier) and hence its implementation of social risk management practices. Moreover, it has been underlined that cooperation and long-term relationships between focal companies and suppliers is key in the implementation of social responsibility [26]. Yawar \& Seuring [27] further affirm that the successful management of social issues in supply chains demands trust and commitment, which require collaboration and supplier development strategies to ensure social improvements in supply chains. Huq et al. [49] use different terminology and declare that monitoring, collaboration and innovation are the necessary social management capabilities of a company. Zorzini et al. [28] use the literature on socially responsible sourcing to suggest that it is necessary to classify areas of interest such as strategy, organizational culture, risk management, transparency, and how they impact upon performance. Among other findings, the importance of transparency has been emphasized and research gaps in all five areas are provided. For instance, the implementation process still remains insufficiently investigated and in terms of transparency one should consider incorporating western-based codes and certifications into developing country supply chains [28]. Huq et al. [49] observe that future research directions should concentrate on countries such as Vietnam and that there is a need for an inductive theory in this specific field [49]. In sum, socially oriented literature reviews highlight the significance of considering the supplier perspective in future research, especially in developing countries [19,26-28].

\subsubsection{Social Sustainability Issues in the Apparel Industry}

Mainly based on the International Labor Organization (ILO) and United Nations organizations, Yawar \& Seuring [27] summarized the social issues that usually appear in supply chains. These include labor conditions, child labor, human rights, health and safety, minority development, disabled/marginalized people inclusion, and gender. While these social issues provide general conclusions, the apparel industry faces major challenges specifically concerning labor conditions which include low wages, overtime work and the formation of unions, but also child labor and health and safety due to its buyer 
driven characteristics [26,29,34,37,41,42,59-61]. In fact, the buying practices of apparel retailers are one of the major contributors to the forlorn situations in apparel factories and the contradiction is clear. The demand for shorter lead times, higher quality products, and cost pressures cause social problems, however, apparel retailers still insist on compliance with standards or codes that cannot be managed by factory managers [29]. This paradox leads to negative socially responsible outcomes [29,38]. Baskaran et al. [34] identified child labor and long working hours as primary violations by investigating 63 textile and clothing suppliers located in India. Yu [37] shows how a well-known footwear retailer constantly seeks low prices, and this applies huge pressure on their suppliers as it is impossible to achieve a competitive advantage to ensure orders and simultaneously maintain compliance with acceptable working conditions [31,37,62]. Oelze [62] further observes that the intrinsic motivation of textile suppliers to be sustainability oriented is often missing but also mentions that governmental regulations, lack of knowledge, and competitive pressures are hindering factors [62]. In this regard Huq et al. [38] report how the buyers' behavior leads to negative outcomes, forcing suppliers in Bangladesh to engage with mock compliance to cover overtime work. Further, Locke et al. [63] compared two Mexican garment suppliers to Nike and found how a distrustful, arms-length relationship merely based on compliance with less frequent and more formal communication between the retailer and the supplier resulted in the payment of low wages and overtime work at the factory [41]. Anner [59] coded the audit reports of the Fair Labor Association (FLA) between 2002 and 2009 and found evidence that, in Vietnam, health and safety, wage and overtime work were primarily detected during audits [59]. Moreover, Baskaran et al. [64] reported that suppliers in India were facing issues with overtime work due to unpredictable orders from the retailers. Stigzelius \& Mark Herbert [65] support this finding with their discussion that apparel retailers put higher pressure on suppliers to offer lower prices and reduced lead times $[5,10,33]$ in order to conform to the frequently changing fashion market [65]. In their paper they note that apparel buyers are not willing to pay more for the products, even if a supplier is compliant with the Social Accountability International Standard (SA8000), which increase accreditation costs for the supplier and result in further expense [65]. Jiang et al. [31] concludes that the textile and apparel industry is buyer-driven and leads to cannibalistic competition among suppliers in China. From the suppliers view, another fact is that corruption, especially in developing countries, is evident [31]. Suppliers can circumvent penalties with briberies paid to government labor agents [38]. During interviews with garment supplier workers in Vietnam, one worker stated that they are taught what to say to auditors. Hoang and Jones [61] summarize that workers support their companies by cheating the auditors, and this is a result of the pressure that buyers place on the suppliers and the threat of order cancellation. Very striking are the reports of academics who observe that the socially responsible practices proposed by western retailers are merely launched for instrumental reasons $[26,37,38]$. Media also stresses this fact, as even the Ethical Trading Initiative (ETI) was recently negatively spotlighted [43].

\subsubsection{Social Management Strategies}

As a consequence, apparel retailers conduct social management strategies [27], social risk management practices [26], or build up their social management capabilities [49] in order to respond to and mitigate external risks. As different researchers use different terms in SSCM literature, this can lead to confusion, however, one needs to note that these abovementioned three terms comprise similar underlying actions to ensure social responsibility [26].

In response to the possible social issues emerging in apparel supply chains, focal companies (apparel retailers) typically launch compliance strategies, which include codes of conduct and standards, auditing and monitoring $[13,27,29,38,41,42,61,66]$. These regulations ultimately cover social and environmental standards throughout the supply chain and are considered as mandatory for suppliers to commit to and gain orders from retailers [67]. With regards to social issues in the apparel industry, Huq et al. [38] identified employee wages and benefits, child and forced labor, workplace harassment, and working hours and conditions as key aspects of codes of conduct [38]. Although 
codes of conduct gained much criticism, especially to be instrumentally used $[29,38,42,61,63,68]$, they still remain the most commonly used practice by apparel retailers $[27,29,69]$. Nevertheless, from the apparel retailers point of view, it becomes increasingly difficult to monitor, hold control, and implement codes of conduct in all factories, including further tiers such as subcontractors, within the entirety of their supply chain $[57,61,68]$. As the buyer-driven characteristics in the apparel supply chain increase, codes of conduct will be inefficient and force suppliers to non-compliance [26,29]. Once apparel retailers engage in codes and standards, it subsequently results in the assessment of the suppliers' social performance based on the apparel retailers' codes of conduct or other standards developed through multi-stakeholder initiatives (MSIs), which play a significant role in the apparel industry and are employed by apparel retailers to increase their credibility and legitimacy $[12,13,26,27,65,70-72]$, and also to reach the reputational protection summarized in [59]. Mostly, such multi-stakeholder initiatives usually establish their own codes based on ILO standards and have their own monitoring systems, which are generally conducted by external organizations regarded as third party monitors/auditors, in addition to the first- and second party monitors/auditors [58]. In this regard, O'Rourke [71] specifically evaluated the leading multi-stakeholder initiatives in the apparel industry such as the Worldwide Responsible Accredited Production (WRAP), Social Accountability International (SAI here referred to as SA8000), Ethical Trading Initiative (ETI), Fair Wear Foundation (FWF), and Worker Rights Consortium (WRC), and their respective codes. Overall, positive evidence of the implementation of SA8000 can be found in the papers of Ciliberti et al. [70,73], who propose that, besides improving the social circumstances in a factory, the initiatives also reduce information asymmetries between supply chain partners and hence decreases overall coordination costs [70,73]. Moreover, Stigzelius and Mark-Herbert [65] discuss how the SA8000 results in benefits to factories as they will enhance the corporate image and decrease labor turnover. What results is confidence, competitiveness, and differentiation with the aim to gain orders from retailers with an ethical awareness profile. However, obstacles to the adoption of SA8000 become evident as there is a lack of support from retailers, especially in sharing in the costs of auditing and certification [65]. Using evidence from the clothing industry in Bangladesh, Huq et al. [49] provide a framework for audit and compliance capabilities. First, they differ between supplier-arranged audits (suppliers who employ standards and the respective codes from MSIs, such as SA8000, WRAP or the Business Social Compliance Initiative (BSCI)) to subsequently become certified by third-party auditors and buyer-directed audits, who base their audits on the clothing retailers' codes of conduct and then either are assessed again by third-party auditors or the clothing retailers' internal auditors (second party audit [58]). Each stream has led to different results in supplier compliance. The buyer-directed approach with internal auditors leads to positive outcomes at the supplier level, such as training and education for workers, and substantive dialogue between clothing retailers and suppliers that result in improved supplier compliance. The third-party auditing, which can be a part of buyer-directed audits or supplier-arranged audits, has been described as merely being symbolic and generally end up in mock compliance [49]. However, this seems contradictory to the abovementioned findings of Ciliberti et al. [70,73]. In sum, monitoring and auditing are performance measurement strategies that check for conformity with required codes and standards as required by the retailers $[27,58]$.

Finally, compliance strategies are not merely operationalized but also documented, reported and communicated [26,27]. Yawar and Seuring [27] propose communication strategies as another substantial socially responsible supply chain action. These include activities such as corporate reporting, also termed sustainability reporting or corporate responsibility documents and labelling [27]. Typically, research on reporting and labelling sustainability in the apparel industry is dedicated to a focal company's CSR operations to disclose and inform external stakeholders. Hence, it is intended to mitigate risks by enabling transparency, accountability and credibility, but also to educate customers and increase awareness [13,26,66-68,74-77]. Nevertheless, studies that deal with the evaluation of apparel companies' reports are helpful to learn about the internal use of reports $[13,78]$. This is more suitable to the aim of the paper at hand, as the researchers investigate 
the relationship between an apparel sourcing intermediary and its supplier base, deviating full focus on public disclosure to external stakeholders such as end-consumers, media, or non-governmental organizations. Therefore, the communication strategy suggested by Yawar and Seuring [27], is adapted for the purpose of the study at hand and extended with other researchers' ideas. According to Turker and Altuntas [78], the communication between buyers and suppliers is an essential key in building the trustful, long-term relationships mentioned earlier. Based on a content analysis of a well-known fast-fashion company's reports, they summarize communication methods and highlight their importance in SSCM, but also note that cross-cultural perspectives need to be considered by firms when communicated to suppliers [78]. This view is also supported by Zorzini et al. [28], who state that transparency (to stakeholders) is ensured through reporting, codes of conduct and ethical standards (MSI accreditation), and they underline the need to incorporate cross cultural views. In fact, although finding evidence from other sectors, Busse et al. [79] note that spatial distance, linguistic distance, and cultural distance all significantly affect communication efforts between actors and hence affect supplier development for sustainability. Similarly, but noteworthy in this regard, Awayshe and Klassen [57] investigated the organizational, cultural and geographical distance of socially responsible practices. It turns out that the distance problematic especially affects communication efforts, such as the documentation of social audits and compliance. For example, a study by Ciliberti et al. [73] on SA8000 reveals that buyers need to rely on local institutions, such as NGOs, to be additionally safeguarded, especially when western based codes are required but may be hindered by geographic and cultural distance. In other words, as distance is increased, supply chain actors need to make sure that western based codes are comprehensive in their meaning and application [73]. Further, Mamic [13] reports that codes of conduct are a substantial part of supplier development whereby corrective action plans (CAP) play a central role. Once any audit has been conducted, for example in achieving MSI accreditation by a third party auditor [72], a remediation system (CAP) is developed if violations according to the required standard have been detected [13]. In this regard, Milne et al. [72] depict the process of how an apparel retailer addressed the obligations for accreditation by the FLA in its supply chain [72]. Ciliberti et al. [80] outline the accreditation for SA8000, based on five apparel companies as case studies [72,80]. Ciliberti et al. [80] further reveal that companies face huge barriers with the integration of CSR in developing countries, especially due to the communication gaps and lack of information that derive from cultural and linguistic distance. Lastly, the lack of knowledge regarding sustainability issues in the buyer-supplier relationship has been found to be a hindering factor for collaboration efforts between the two actors [62].

In this context, Yawar and Seuring [27] point to the significance of collaborative and long-term partnerships between the actors of a supply chain, because this ultimately leads to an enhanced adoption of socially responsible actions and supports the implementation of codes and standards throughout the apparel supply chain $[14,27,36,41,61,62,81]$. Accordingly, such collaborative relationships or interchangeably used long-term relationships can be established through direct and indirect supplier development strategies [27,82]. Based on the explanation given by Huq et al. [49] collaboration “...involves skills, processes and practices that improve a firm's coordination with its suppliers, consumers and other stakeholders to jointly improve social outcomes". While direct supplier development strategies like training and education initiated by the buyer will support suppliers in handling social issues [38], financial and technical investments at the supplier level will enhance their capabilities in managing social issues. On the other hand, indirect supplier development strategies, such as supplier evaluation and informal auditing, initiated by the buyer will have encouraging effects on the supplier to facilitate social sustainability [27]. In fact, providing training has been found to be effective; Ansett [67] shows how an apparel company was able to improve wages in its supply chain and provide benefits for factory managers and workers [67]. Based on a survey, Sancha et al. [82] found a positive relationship between supplier development practices and the supplier's social performance, for example in human rights and child labor employment at the supplier level [82]. Perry and Towers [14] underline the importance of long-term partnerships between buyers and suppliers, accompanied by trust and 
commitment in order to cut costs [27] and improve CSR performance. They mention how suppliers who collaborate with buyers can reduce uncertainty and lead times, which consequently positively affects suppliers in coping with orders and to conform with social sustainability requirements [14]. Carter and Jennings [83] discuss how trust in the buyer-supplier relationship triggers the willingness of buyers to provide help and support to suppliers and jointly solve problems once they emerge [83]. Based on the investigation of a well-known apparel retailer, Locke et al. [41] picture that frequent visits and open communication between a buyer and its supplier brings trust and a greater working relationship between the actors. In that regard Locke et al. [36] show that a commitment-oriented approach between buyers and suppliers is complementary to the traditional compliance-oriented approach, which enhances labor conditions in the supply chain. Drivers for embracing commitment relationships are mutual benefits, such as learning, capacity building, positive incentives, and respect. The underlying approach to a commitment-oriented strategy is to uncover, analyze, and correct root causes for non-compliance. They further emphasize related mechanisms, such as joint problem solving, information sharing, trust and reciprocity, and characterize the dynamics of mentoring and coaching [36]. Finally Grimm [58] outlines 14 critical success factors for the implementation of sustainability standards among suppliers and sub-suppliers (subcontractors). Among others, trust between focal firms, suppliers and sub-suppliers is a striking factor for establishing strategic supply chain partnerships, but also geographical and cultural distance are mentioned as important. Further Grimm et al. [84] stresses that code and standards implementation are hindered due to a lack of transparency and missing contracts with suppliers and sub-suppliers and their unwillingness to commit and be involved with one another. They suggest that focal firms should be engaged with direct supplier involvement, which in turn increases trust and maintains an awareness of sustainable responsibility $[58,84]$.

In sum, it seems that there is a sequential process in developing collaborative relationships, thus companies should first engage with supplier development strategies where trust and commitment are obviously critical antecedents $[27,83]$. It is important to note that each social management strategy is not exclusive and thus not necessarily independent from each other. Ultimately, the strategies support the implementation and assessment of codes and standards to ensure social responsibility across the supply chain [27].

While the perspectives described above do not explicitly integrate sourcing intermediaries, conclusions, especially for the apparel industry, fall too short, therefore calling for a more detailed study on apparel sourcing intermediaries to investigate how the adoption and implementation of social management strategies in the supply chain [19] may change or be facilitated, which leads to the following two research questions:

- RQ1: Why are Vietnamese apparel suppliers (sourcing intermediaries and factories) tackling social issues?

- RQ2: How are Vietnamese apparel suppliers (sourcing intermediaries and factories) tackling social issues?

The next section explains how the underlying theory of social sustainability supply chain management can be linked to the role of the apparel sourcing intermediary by specifying the current gap and justifying the third research question of the study.

\subsection{Linking Sourcing Intermediaries in Apparel Supply Chains to Social Sustainability}

As learned earlier in this paper, apparel retailers shifted production to international low-cost suppliers and this increases complexity in the management and control of the supply chain $[1,15,52]$. The primary motives to engage in global supply chains is cost reduction and speed [1,15], but further significant drivers can be found in the paper of Jia et al. [7], such as access to scarce raw materials. Logically, it is not surprising that the outsourcing strategies of apparel retailers result in a complex and intertwined supply chain. In this regard, Perry and Towers [14] critically point at the exchange of information and the importance of the relationship between all actors within the complex and extended 
nature of the apparel supply chain [14]. Consequently, besides direct sourcing structures where apparel retailers directly deal with factories, apparel retailers can set up a mediated sourcing structure i.e., where a third party intermediary is in between and consolidates the demand of one or more apparel retailers and sources the garments for each of them from its supplier base [51]. In other words, apparel retailers set up different methods in the form of strategic global management departments or subsidiaries in foreign countries, which act as international purchasing offices (IPOs) $[7,85,86]$ or employ third party (external) sourcing intermediaries such as full service providers and agents $[1,6,15,33,51,52,55]$ who will support focal companies with the management of globally dispersed suppliers to overcome common barriers and find opportunities in their global purchasing strategy. Interestingly, not many papers can be found investigating the role of intermediaries in the apparel industry $[1,6,15,33,87]$ and it is very striking that research still shows a lack in dealing with the role of apparel intermediaries in terms of the management of a sustainable supply chain.

Basically, sourcing intermediaries can manage sourcing, supplier quality control, shipping management and distribution tasks for apparel retailers [3,15]. Interchangeably as defined by Jia et al. [88] an intermediary ISO (international sourcing office) may include the use of a third party trading company by a focal company. In their case study, they focus on IPOs, defined as an intra-organizational unit (a part of the buying company), differentiate five types of IPOs and highlight their integration to a focal company based on their roles and activities. The role theory in their study comprise the following routine roles of IPOs: gatekeeper, negotiator, coordinator, supplier's advocate, supplier developer, cultural broker, internal advisor, and other supports. Further, they made distinctions based on the strategic roles carried out by the five types of IPOs: supply policy maker, network structuring agent/network orchestra, innovator, and knowledge broker. Finally, they propose that more research is needed, especially at the intermediary ISO stage $[86,88]$. Although their conclusions are with reference to other industries rather than the apparel sector and focus on IPOs, they are highly supportive in understanding why focal companies hire intermediaries in their supply chains.

Another detailed picture about the key responsibilities and interplay with the focus on apparel supply chain actors, i.e., of retailers, sourcing intermediaries and factories, is provided in the study of Neu et al. [33]. In general, apparel retailers seek out intermediaries to find advantages in managing the rising complexity of their supply chains, especially in collaboration and communication concerns [1]. The high volatility of the respective apparel sourcing countries and their communications turn out to be a major problem when dealing directly with manufacturers located in foreign countries. This primarily evolves due to cultural, linguistic, and industry structure reasons [87]. Despite geographical and cultural distances between retailers and their overseas suppliers, Popp [87] illustrates how the use of intermediaries improves supply chain performance by lowering information costs, economies of scale and scope, and creating a value adding effect [87]. These value adding effects can be described as orchestrating and coordinating networks by managing the capabilities of the information and material flows of the sourcing intermediary [1]. Based on a case-study with two UK fashion retailers, Purvis et al. [15] further confirms that, especially for mid- and high-fashion items that are produced globally, the use of intermediaries is highly beneficial. Major reasons include high flexibility (see also [6]) and independent global sourcing in an increasingly complex global supply chain, which is reflected by financial, managerial and technical knowledge of intermediaries in the local environment of the suppliers' countries. This expertise helps to organize a dispersed production structure and enhances lead times, enables lower costs for supplier search, as well as negotiation with suppliers, and monitoring costs [6,15]. Indeed, Cook and Kozar [6] discuss the competitive advantages of employing sourcing intermediaries who effectively manage cost and pricing strategies in order to save money for apparel retailers. In their study, they reveal that sourcing intermediaries enable cost reductions by finding the factory with the lowest price, which leads to a highly competitive situation between factories but consequently supports a race to the bottom. One common way conducted by the intermediary is the organization of competitive auctions [1,33]. As a result, from the retailer's perspective, the use of intermediaries will also decrease fixed costs in the development of an apparel 
supply chain and increase flexibility [6]. According to Masson et al. [1] they act as network coordinators, manage information and material flows and network orchestrators or coordinators [1]. In other words, intermediaries act as hubs who bring all actors in the supply chain together to manage effectively their linkage and expertise. Noteworthy are the findings from Zhang et al. [89], who use the term boundary-spanners and show how agents within the food and automotive industry generate trust between the actors through an agent's strategic communication and professional knowledge. Moreover, as Purvis et al. [15] affirm, intermediaries enhance visibility to retailers further up the supply chain and also provide opportunities to local suppliers who engage new markets. On the contrary, slow-fashion items (basics such as white t-shirts) with high volumes are sourced globally in low cost countries, but without intermediaries, as apparel retailers prefer to source directly by building up-close and stable relationships [15]. Conflicting with the findings of Zhang et al. [89], this would lead to the conclusion that the use of intermediaries will be a hindering factor in establishing collaborative and trustful relationships between retailers and factories. Indeed, as learned earlier in this paper, close relationships and collaboration efforts act as major contributors to improving social responsibility, yet the sourcing intermediary seems to be an obstacle [1]. In the paper by Masson et al. [1], the analyzed retailers showed little to no evidence of a relationship to the garment manufacturers. They point at the significantly high dependency of western retailers on intermediaries who are located in low-cost countries. This causes high risk, as many of the retailers in their study are not even aware of which suppliers manufactured their products, which leads to a lack of control and transparency, thus leaving them vulnerable to child labor scandals [1]. Furthermore, Neu et al. [33] discuss how risks based on the buyer-driven requirements provided to the intermediaries are passed along via written contracts. In case of failing, (on time delivery) high financial penalties can be alleged by the retailers [33]. This pressure of course will then be put onto the suppliers to manufacture the goods on time, which inevitably leads to social issues such as overtime work. In this regard, Köksal et al. [26] clearly point at the barriers in the implementation of social sustainability in apparel supply chains. For instance, to conform with the buyer requirements, multilevel contracts with various vendors and subcontractors are signed, which raises the complexity and in fact this is not a seldom case, especially in the apparel industry [26,67,87]. Interestingly, Awaysheh and Klassen [57] discuss that trust and communication between buyers and suppliers will suffer the longer a supply chain becomes, results that are counterproductive to communication, supplier development, and compliance strategies. Finally, they suggest that future studies should elaborate on collaboration and supply chain length to better understand each factor [57].

As a consequence, with the aim to circumvent uncertainty by the length of a supply chain, apparel retailers should consider socially responsible practices (compliance strategies), such as the use of third party audits that will certify factories based on MSI standards, which is a common way to gain legitimacy, safety, and mitigate stakeholder pressure $[13,26,71]$. Still, these standards turn out to be problematic, as evidence from Vietnamese managers shows that sourcing intermediaries prepare their subcontractors for upcoming audits in order to ensure that the focal companies do not stop buying the vendor's products [61]. This of course is attributable to the likelihood of corruption and mock compliance in a developing country's factories as the researchers reveal in apparel supply chain studies $[36,38,61,80]$.

Briefly, despite all the above mentioned possible operational shifts from retailers to the intermediaries the paradox is at hand: researchers primarily found that price and lead times are the most critical factors for hiring sourcing intermediaries. This again is counteractive to the implementation of social sustainability and due to the nature of lengthening the supply chain one can assume that intermediaries act as hindering factors in implementing socially responsible strategies. Generally, the suggested theory on social management strategies requires direct relationships between a focal company and its suppliers. This is particularly interesting, because as learned earlier, the relationship between the retailer and the factory will be significantly interrupted by hiring intermediaries. On the other hand, previous research has clearly shown how intermediaries can 
facilitate huge advantages to focal companies due to their expertise and the specific roles they carry out. Logically the question arises, how the suggested social management strategies can be implemented when focal companies use intermediaries to supply their products from foreign countries. More specifically, it will be interesting to investigate whether and how the apparel intermediary's capabilities and skills can be helpful and applicable in implementing social sustainability in apparel supply chains. This leads to the third research question of the study:

- RQ3: How do apparel supply chain actors perceive the role of the apparel sourcing intermediary for the implementation of social management strategies?

Based on the current call for more evidence from developing countries, the suppliers' perspectives and social sustainability $[26,28,38]$, this study will show why and how sourcing intermediaries can act as enablers for the implementation of socially responsible strategies, and thus highly contribute to the existing theory that widely neglected the role of apparel sourcing intermediaries in terms of social sustainability. Moreover, this study follows suggestions of the Yawar and Seuring [27], who encourage academics to find empirical evidence in supplier development strategies across supply chains.

Given the collected information on social sustainable supply chain management and the exploratory nature of the paper at hand, it is beneficial to develop a model that will support the analysis and organize the findings. More specifically, in order to explore the theory-driven research questions (RQ1, RQ2, RQ3) [90], the outlined theoretical framework in Figure 1 supports the empirical research and helps to organize and manage findings and their analysis. The theoretical framework mainly draws on the social SSCM contributions of Yawar \& Seuring [27] and applies, in addition, the ideas of Köksal et al. [26] in order to enrich their proposed framework with the study at hand. While the existing dominant conceptual frameworks detect three important actors in SSCM, it is vital, especially for the apparel industry, to extend the perspective with another significant actor: the sourcing intermediary. Accordingly, the findings of the paper at hand should help to extend and refine the existing knowledge and frameworks on social SSCM theory with novel contributions by integrating the role of the sourcing intermediary in apparel supply chains.

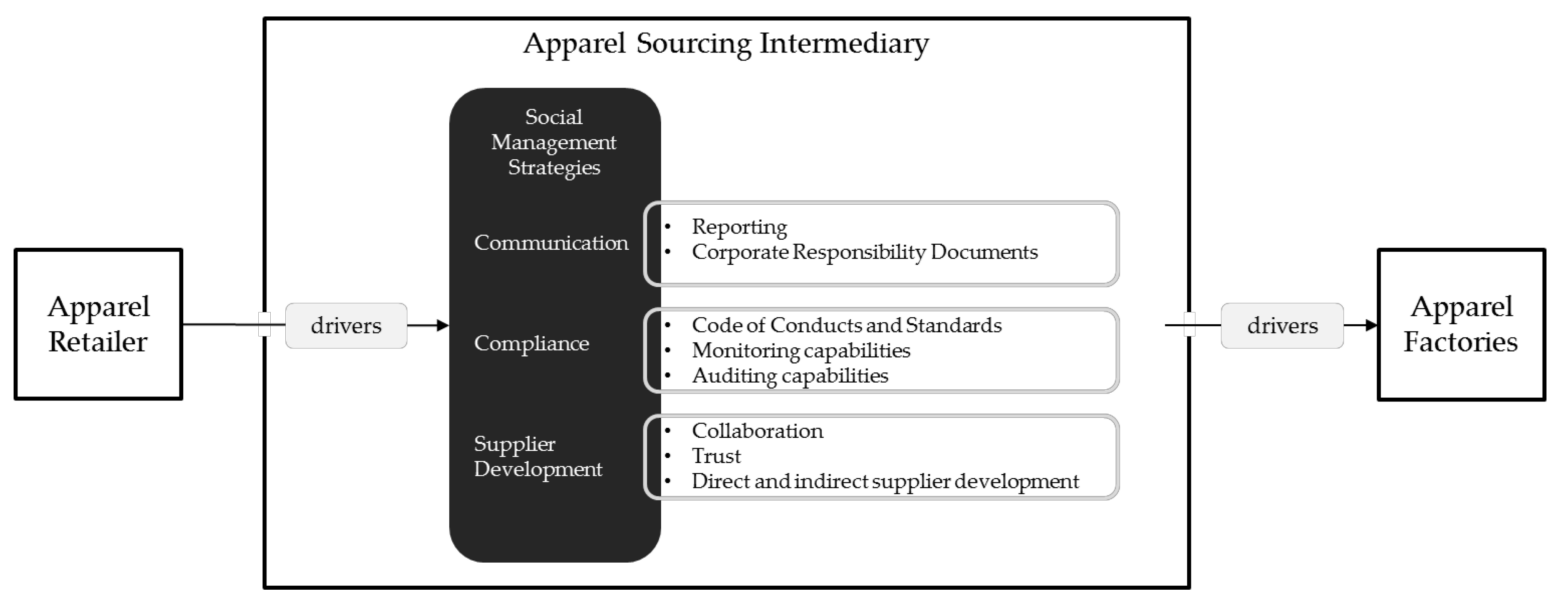

Figure 1. Theoretical framework of the study mainly based on Yawar \& Seuring (2015).

\section{Research Methodology}

\subsection{Method}

As the field of apparel sourcing intermediaries and social sustainability is still in its very early stages, especially for the role played by apparel sourcing intermediaries in managing and implementing social sustainability within a supplier base, this study conducts a multiple case study method that is exploratory in nature [90-92]. So far case study research has been used by researchers 
to examine supply chain management topics and the research follows such leading academics as Eisenhardt [91] and Yin [93], in addition to examples of existing exploratory cases [1,49,73,94-97] and suggests step-by-step guidelines for conducting new case studies [96-102]. As highlighted by scholars, a multiple case study design has its strengths in finding more convincing and robust evidence, which will increase generalizability and allow for a deeper exploration of the outlined research questions when compared to a single case-study $[90,92,93,103]$. Furthermore, the chosen research design is justified by the form of this study's research questions "why" and "how", with the aim to investigate a contemporary phenomenon in a real-life situation accompanied by the fact that the researcher has no control over behavioral events [91,93]. Additionally, case study research is an appropriate approach to build on and extend but also to develop theory in response [90,92,93,99,100,104]. To enhance the research quality and ensure rigor during the research process, the researchers conducted the five-stage research process described in the following paragraphs (i.e., research question, instrument development, data gathering, data analysis, and dissemination), proposed by Stuart et al. [102].

First, the researchers examined the relevant literature and linked apparel sourcing intermediaries to social sustainability in supply chains where contradictions and research gaps were highlighted. Specifically, the apparel industry is often confronted with social issues as emphasized earlier in Sections 2.1 and 2.2, thus it serves as a proper field of application. Based on this, research questions (RQ 1-3) have been formulated. Ultimately, as this study is exploratory in nature, inductive findings are of special interest during analysis [105-107], thereby aiding the development of novel propositions or inductive theory $[90,106]$.

When building theory from case studies, case selection using replication logic is suggested [100] and the case companies were selected so that each predicted similar results (literal replication) [92,93]. Thus, a smaller number of cases is acceptable and multiple case studies with four to ten cases are sufficient to find evidence [91]. Further, the cases ideally should meet the following criteria: all suppliers are physically located in a developing country and active in the apparel industry; all apparel factories process orders from sourcing intermediaries as their customers; and all suppliers supply international apparel retailers. It is also required that the case apparel factories are diverse in their size, order quantities and their year of establishment [100]. Purposely, the researchers sought out apparel intermediaries and found one apparel sourcing intermediary based in Vietnam and who was contacted, visited and interviewed as a part of the supplier base. Moreover, the researchers contacted one of the intermediary's customers, a western apparel retailer, which resulted in six appropriate cases. Hence, all of the criteria for appropriate cases have been met and the declared unit of analysis is the apparel sourcing intermediary.

Due to the exploratory nature of this study a total of eight face-to-face semi-structured interviews lasting 60-90 min each were conducted on three stages in the supply chain: the apparel sourcing intermediary and four of its related Tier 1 factories, and a well-known apparel retailer who sources via the mentioned intermediary from Vietnam. Although not all sustainable supply chain actors are involved (supply chain stakeholders), the three stages mentioned above allow us to examine a companies' actions and their interaction, which is of special interest in this study [99]. Interviews have been declared as one of the most important sources in a case study [93], which according to Saunders [107] provides the opportunity to open a discussion, collect contextual and background material, and to understand relationships. Hence, the researchers prepared an interview guideline based on the theoretical background of this study (see Appendix B), which ultimately should provide deep insight into why and how the cases adopt social management strategies (communication-, compliance-, and supplier development strategies) and what role the sourcing intermediary plays in the implementation process.

To answer the research questions of this study, the authors followed qualitative content analysis, which is an appropriate tool to assess the interview material and analyze its verbal and formal content [105]. The semi-structured interviews, as well as all additional secondary data and follow up E-mails of the six cases were analyzed separately by evaluating text passages and coding them 
in compliance with the suggested categories of the outlined theoretical framework in Figure 1 . In that regard the professional QDA-Software (Qualitative Data Analysis-Software) MAXQDA (www.maxqda.com) has been employed for qualitative data analysis. As the a priori categories and dimensions are theory-based and have been clearly defined, the transparency and objectivity of the research process is given and increases the coding reliability. As suggested by Eisenhardt [91] and Voss et al. [100], within-case and cross-case analysis were conducted to investigate the cases $[91,100,108]$. First, within-case analysis was performed as the interviews were each individually analyzed case by case. This allows the researchers to become familiar with each case company independently and may evolve unique patterns before generalizing across the cases $[91,100]$. The subsequent cross-case analysis will then help to find categories, themes or typologies for the conceptualization or supports in building considerable theory, which is likely to offer an integrated framework covering all the cases of the study $[96,106]$.

Therefore, one tactical approach is to select categories or dimensions that derive from the existing literature to examine patterns across the cases [91,108]. Yin [93] further observes that a good case study will benefit from the development of a priori theory, which will be helpful in defining the right research design and the data to be collected [93], regardless of how inductive the approach will be for theory building [100]. In fact, by following replication logic [92] in multiple case studies the development of a rich theoretical framework is crucial to analyze the data, which aims to find similarities across the cases and thus strongly support triangulation, adding to generalizability and validity of the findings $[91-93,100,107]$. The theory on social SSCM deriving from the literature review serves as the theoretical framework [106] (Figure 1), which helps to organize, manage, and comprehend the material collected and explore the research problem outlined in this study. Additionally, in terms of validity and reliability, the content analysis research can be enhanced with the involvement of one more researcher during the data search and analysis. Therefore, inter-coder reliability was ensured as the cases have been analyzed and coded by the contributing researchers separately [109]. Lastly, the results have been discussed with the involved researchers to find an agreement with the most prominent and striking codes in order to finalize the results. To further ensure the quality of the results, the researchers addressed the validity and reliability by performing the dedicated tests proposed by Yin [93]. Finally, by using the pattern-matching technique $[92,93,104]$ the semi-structured interviews were examined in order to find evidence from the results that may match or not match the researchers' literature review.

\subsection{Case Description}

Table A1 provides relevant data about the six case companies, whose identities are protected in by code names: RetA, IntA and FactA-D. IntA, a subsidiary company, belongs to a global apparel company headquartered in Hong Kong, which has its expertise in apparel and accessories sourcing and is a supply chain partner to well-known leading apparel brands. More specifically, the global apparel company is a full-service provider, globally active in more than ten countries, including offices in China, Sri Lanka, Indonesia, Bangladesh, Turkey, Spain, and New York, who employs around approximately 1500 workers worldwide. Each sourcing office is independent and free in its decision taking. IntA, as one of its global offices is located in Vietnam, employs approximately 150 workers. They offer expertise and services, especially in research and development, logistics, market intelligence, merchandising and outsourcing, quality assurance, -control, -engineering, -monitoring, and -auditing, shipping, social and chemical compliance, and sourcing. IntA's major customers include well-known apparel retailers mainly located in the USA and Europe and provide both men's and women's contemporary wear, casual wear, and active wear. Their product expertise lies in circular knits (t-shirts, polo shirts, sweatshirts), coordinates, denim, dresses, flat weave bottoms (chinos, cargo pants, 5-pocket pants, and skirts), indoor jackets, men's shirts, and outdoor jackets. Their supplier base comprises 35 apparel factories all located in Vietnam. The researcher found access to four apparel factories (FactA-D) which include factories of IntA's supplier base with very high and low quantities manufactured for 
IntA, and thus this enhances representativeness for the whole supplier base. In 2016, the quantities manufactured by Fact A ranged about 120.000 units, Fact B 350.000 units, Fact $C 710.000$ units, and Fact D 160.000 units, all for IntA. IntA promises lead times between 75-90 days to its customers. Finally, as one of IntA's customers, RetA is a global apparel company located in Europe. The company includes different brands which are active in various segments and offer various product categories globally. The company's annual turnover in 2016 was over five billion Dollars and it employs around 15,000 workers around the world. Moreover, RetA sources from more than 38 countries, including a network of over 1200 factories, sourcing directly from factories or via intermediaries. Furthermore, its own Code of Conduct and standards are assessed in each factory they are sourcing from and RetA is committed to the FLA and Better Work program in some of its sourcing countries (Vietnam).

Although the researcher had the possibility to meet more than one expert within a company (IntA, FactB, and FactD), the interviews with case FactB and FactD are summarized as one interview each. The interview with these experts took place at the same time and sometimes they merely had a confirmatory effect, while just one expert was actively discussing with the researcher. At FactB, the major interview partner was the Head of $R \& D$ and was accompanied by the Compliance Manager of the company. The primary interview partner at FactD was the Compliance Manager, while the Vice Director as well as the Merchandise Manager were only confirmatory and complementary. Luckily, in every case key informants on the topic (Compliance Managers or the Corporate Responsibility Coordinator for RetA) took part. It is noteworthy that the interviews with IntA's managers (Country Manager (CM), Compliance Manager (CompM), and Head of Quality Assurance/Quality Control \& Technical (QC/QA)) were conducted independent from each other, thus they were evaluated and analyzed exclusively. Depending on the interviewee's preference, the interviews were carried out in English or Vietnamese and translated when necessary. All interviews were audio recorded and transcribed. Further, the researchers had multiple chances to discuss findings with the sourcing intermediary but also to contact the experts via follow-up mails to validate the results. The fact that all the apparel factories are part of the sourcing intermediary's supplier base and RetA is a customer of IntA supports our triangulation. In addition, visits to all of the case companies' offices and related factories allowed us to take pictures and notes on the spot. This collection was further supplemented with multiple sources of secondary data in the form of sensitive company documents, such as detailed company profiles, current social compliance status, historical, actual and upcoming audit documents and reports, corrective action plans, companies' own social compliance checklists, historical sustainability documentations, social compliance presentations for trainings and education, and websites, all of which sufficiently enabled triangulation [93].

The results are presented and discussed in the following section by taking note of other researchers recommendations on how to report theory-building case studies in a clear and comprehensive way $[90,96,110]$, with the goal to explore the research questions and thereby enlighten the role of the apparel sourcing intermediary for the implementation of social sustainability. Readers of the paper at hand should note that the researchers only present findings from the cross-case analysis.

\section{Results}

Recall the outlined research questions of this study:

- $\quad$ RQ1: Why are Vietnamese apparel suppliers (sourcing intermediaries and factories) tackling social issues?

- RQ2: How are Vietnamese apparel suppliers (sourcing intermediaries and factories) tackling social issues?

- RQ3: How do apparel supply chain actors perceive the role of the apparel sourcing intermediary for the implementation of social management strategies?

In order to answer RQ1 and RQ2 the analysis is separated into two parts: first, the researchers strive to understand the factories' and sourcing intermediary's motivation for social sustainability, 
particularly why they implement social sustainability strategies. The second subsection then provides a better understanding of how social sustainability is implemented, especially through the apparel sourcing intermediary (IntA), which provides indications of their activities during the implementation process. Based on the results, the researchers exclusively discuss the role of the apparel sourcing intermediary with regards to social sustainability in Section 5 and hence answer RQ3.

\subsection{Understanding Motivations for Social Responsibility in Vietnam}

In sum, a clear picture can be drawn based on the motivational factors for embracing social responsibility. Major themes that appeared during the analysis were NGO pressures, government pressures, business eligibility, and investment reasons, which are summarized in Table 1.

Table 1. Social sustainability motivations for Vietnamese suppliers i.e., the independent apparel sourcing intermediary and factories.

\begin{tabular}{|c|c|c|c|c|c|c|}
\hline \multirow[t]{2}{*}{ Motivations for Social Sustainability } & \multicolumn{6}{|c|}{ Evidence from Cases/Supply Chain Actor } \\
\hline & RetA & IntA & FactA & FactB & FactC & FactD \\
\hline NGO and media pressure on buyers & $\mathrm{x}$ & $\mathrm{x}$ & & $\mathrm{x}$ & & \\
\hline Government pressures & & $\mathrm{x}$ & $\mathrm{x}$ & $\mathrm{x}$ & $\mathrm{x}$ & $\mathrm{x}$ \\
\hline $\begin{array}{l}\text { Apparel retailers minimum requirement to conform with MSI } \\
\text { certification: } \\
\text { suppliers gain business eligibility through legitimacy and reliability }\end{array}$ & $x$ & $\mathrm{x}$ & $\mathrm{x}$ & $\mathrm{x}$ & $\mathrm{x}$ & $\mathrm{x}$ \\
\hline $\begin{array}{l}\text { Investment reasons for suppliers: } \\
\text { win big orders } \\
\text { longterm partnerships } \\
\text { keep skilled workers in the factories }\end{array}$ & $\begin{array}{l}x \\
x\end{array}$ & $\begin{array}{l}x \\
x\end{array}$ & $\begin{array}{l}x \\
x \\
x\end{array}$ & $\begin{array}{l}x \\
x \\
x\end{array}$ & $\begin{array}{l}x \\
x \\
x\end{array}$ & $\begin{array}{l}x \\
x \\
x\end{array}$ \\
\hline
\end{tabular}

First, findings show that all the case companies do have a high awareness of social sustainability. IntA's QA/QC explains that after the incident in Bangladesh, Rana Plaza, in 2013 a remarkable shift towards social compliance emerged as western apparel brands were spotlighted more critically and strictly, especially by media and NGOs. RetA and FactB further confirm that NGOs are critical in pressuring western brands to be socially responsible and highlight their powerful role. Therefore, western apparel retailers look to avoid any negative spotlight or harsh media criticism, which can threaten their image, and hence they require MSI certifications or cooperate with NGOs as a matter of safeguarding their business. Consequently, these pressures will be exerted by western apparel retailers on the sourcing intermediary and hence to their supplier base. IntA's QA/QC underlines that social compliance with standards and certifications has become very critical for western customers, which is likely to be a deal breaker and in that regard, IntA's CM clearly states "Social responsibility is one of the primary concerns for us and we will never work with any supplier not aware of that".

According to IntA's CompM “... the buyer always requires its own certification system, like the WRAP certification by the independent third party..." As can be extracted from the company documents and the interview, RetA collaborates with the Better Work program in Vietnam, although they have their own assessment system that is respected industry wide. RetA explains "...within that business the factories are responsible to ensure [social standards compliance], in order to get the business". In fact, all of the interviewed factory managers state that customer requirements for social or ethical standards are one of the most impactful pressures. As such, social certifications create visibility and customers will be attracted to place orders, thus factories gain legitimacy and reliability for doing business. This is often mentioned to be a critical factor and social compliance turns out to be a deal breaker before price, delivery times, and quality is discussed with the intermediary as explicitly argued by FactD and FactC. All interviewed factory managers are clear about the requirements to gain business eligibility. As outlined by FactB, the awareness of being socially responsible with social standards is strikingly high at Vietnamese apparel factories "...it's just like a ticket with the social compliance...if you have this it's like you have a ticket and you can get in the park to play. If you don't have the ticket, you may can also 
play but the security [media and NGO] will catch you one day, because every day is like illegal. If you do well, no problem".

Furthermore, the need for being MSI certified was confirmed by all case factories consistently, as they fear potential order and long-term partnership losses. Thus, the application of MSI certifications in their factories not only makes them business eligible but also it also becomes prominent that they view social compliance as an investment and a significant driver to get big orders and long-term partnerships. This was confirmed by all factory interviewees as they perceive social compliance not as a financial risk due to additional costs but rather as an investment to their factories. For example, FactD argues "...this [social compliance] is also a kind of investment, right?!...we have to spend some money for the investment first until we get the order and we will have then the income".

Additionally, managers claim that the Vietnamese government is strict with its local laws. Except FactA and RetA, all case companies confirm the strict role of the government, even though they are not very rigorous yet set high social requirements. Mostly, they will have an eye on the payment rolls and will pressure factories with penalties. IntA's QA/QC indicates, "As I told you, after the incident with Bangladesh the government has taking very, very strict action on the buildings you know...so, those kind of actions are taken and definitely the salary part has to be as per the law. If they feel any forgery [with payment roll documentation] they just cancel your license... the law plays a very important role here". Highly interesting is the statement by FactB, who argues that the strict regulations and monthly visits from their government are attributable to the current political situation between the US and China, which opens great opportunities for Vietnam to accelerate their export and importance as a global apparel sourcing market. However, in that regard two managers point out that in Vietnam, many things can be handled with bribery and some of the Vietnamese suppliers keep double books. Nonetheless, the apparel factory managers all state that they comply with the legal requirements for salary payment. All factories mention that they pay at least an average income according to the local law.

Moreover, the case factories are engaged with social responsibility to keep their trained and skilled workers. In fact, all factory managers fear the movements of their labor and show a strikingly high interest in binding them as long as possible to the factory by being lucrative with their payments. The problem behind the loss of workers is at hand. Not only that the investments made into a, in terms of their training and education, will be lost, but also highly skilled workers are essential forces to comply with quality and the lead times required by the buyers, as all factory managers consistently argue. FactB outlines critically, "... because you need to train them and if you lost them and have new employees you need to train again so that's why my Boss says, ok, we pay, we pay. [Therefore] no need to do training again about the brands, how to sewing this..." Therefore, paying salaries according to the minimum local law seems not sufficient to keep their workers, thus factory managers go beyond the average payment of salaries and invest in their workforce with bonus payments, as all case factories confirm.

Based on these findings, it can be assumed that the previously discussed theoretical suggestions on social management strategies are shifted from the retailers to the intermediaries. More specifically, not only are pressures and incentives passed on from the retailer to the suppliers, but also communication, compliance, and supplier development strategies are managed and performed by the apparel intermediary. The next section will explore IntA's activities more in depth and therefore provide novel insight on the question of how the sourcing apparel intermediary facilitates the management of social sustainability, with evidence from all cases.

\subsection{The Sourcing Intermediary as an Enabler for Social Sustainability}

As outlined earlier in in this study, a third party intermediary can be employed by the retailer (mediated sourcing structure) to find improved access to proper foreign factories and advantages, most importantly in lead times, price and quality. In this scenario retailers are disconnected from the supplying factories, which turns out to be an obstacle for any social management strategy undertaken by the retailer. Therefore, IntA's CM states “Our main aim is to bridge the gap between our customer needs 
on one hand and what our suppliers can do on the other hand... So if they do not have enough resources and they want to source from Asia, they leverage on our buying power and skills...".

Another three statements from IntA, RetA and FactB address the importance of building partnerships. Retailers are shifting responsibility to the intermediary which is, although being a third party, considered an extension of the apparel retailer. IntA's CM declares "... for us the ideal customer is who really treat us like their own company. They [retailers] feel safe that their brand is protected and they are sure that there will be no sustainable issues". RetA affirms "... we do share a lot of roles and responsibility with them [intermediaries] and we really do appreciate them helping us... they [intermediaries] are your extension. I don't see an intermediary being a separate organism that works on its behalf in this case... so it is a really good partnership" As evidenced by the case companies, social responsibility is passed on to IntA, which in turn demands high degrees of trust between the retailer and the intermediary that result in long-term partnerships. However, social risks remain primarily at the retailers' stage, as they will be spotlighted and scrutinized by any media or NGO once social violations appear in the supply chain. On the question whether retailers are still engaged closely with the factories producing their orders via intermediaries, IntA's QA/QC argues “... retailers do insist, first that they want to have this [any MSI certification] compliance... because retailers do not know sometimes [their supplying factories], so it's based on trust exactly, exactly...".

\subsubsection{Compliance Strategies}

The significance of social or ethical standards has been very clearly described in Section 4.1. It has become evident that MSI certifications are the most relevant and important actions to perform and show social responsibility. Moreover, from the compliance status documents of IntA's supplier base (which includes further factories than the cases FactA-D) it can be observed that only a very little number of retailer audits, based on their own codes and standards, are conducted. This also was observable in each interview because by asking generally about codes and standards all interviewees quickly directed the discussion towards MSI certification and third party audits. This again enlightens the high importance and relevance of MSI certifications but also the shift to social responsibility merely reduced to compliance with social or ethical MSI standards. IntA's QA/QC indicates that they see their responsibility in ensuring any MSI standard requirement by the retailers and gives an example "... so a lot of [our] suppliers they have WRAP certification. But many of our European customers, they do not except only WRAP certification, because they feel it is not enough. So we work with the suppliers who already have WRAP certification and then we work with them within couple of three to four months and we get them BSCI certified".

In order to achieve any MSI certificate factories must undergo third party audits. This was proven by the documents and statements of all factories and interestingly they highlight the importance that non-Vietnamese locals conduct the third party audit, because locals probably would be more prone to corruption whereas foreigners do not take any "under table money" (IntA and FactB) to certify the factory. Indeed, third party audits have been declared as strict, credible and legitimate, however, the case companies explained that it is very easy to get further MSI certification once they already hold one MSI certificate, because they are similar to each other in their contents. For instance, FactB states "... when you do one audit, you can pass all other audits, because it's almost the same, almost the same". The similarities and little differences between MSI certifications, but also across retailers' codes of conduct, were in particular confirmed by IntA and two further case factories. In this regard the Compliance Manager of FactA states "... the buyers [retailers] have all different code of conducts but the main point and main focus is the same. So it is not difficult for us to comply with their code of conduct and their different requirements [MSI standards]". Moreover the CM of IntA outlines that not only audits will be performed, they also take over monitoring actions "... things doesn't stop there, there is a continuous monitoring". Indeed, monitoring activities are performed and all case companies share that IntA conducts frequent visits to the factory to check their current compliance status. This was transparent in their so called "CSR Compliance Status Report" documentation, which included all factories, their current MSI certification, 
the last conducted audit date, the final result of the respective audit, and all upcoming audits and additional remarks (pending improvements and necessary visits to the factories). Finally, IntA goes beyond first Tier third party audit preparation and monitoring and takes responsibility to at least visit and evaluate the subcontractors of any of their supply base factories to reduce possible risks, as IntA's $\mathrm{QA} / \mathrm{QC}$ underlines "... we go and see the subcontractor", while FactB argues "Ok, like this, [IntA] ask us also to make [apparel] with subcontractors but they have people to check the sub-conts. They will find the sub-conts and go there. That's how agents take responsibility".

\subsubsection{Supplier Development Strategies}

Generally, all the cases shared that the sourcing intermediary is the key actor in establishing trustful relationships to both the retailers and the factories. Trust is inevitable to start any collaboration and it is perceived as a mandatory basic factor, providing transparency to the retailer, as RetA and IntA's CM state. IntA's QA/QC agrees that in any case, once trust and transparency is not ensured by the factories because the factory hides anything on purpose (such as keeping double books), they will right away discard and cancel any contract. This provides indications that the intermediary assumes risk management activities. For instance, as mentioned earlier, almost every factory initially used to keep double books, but IntA has been able to convince most of the factories to be transparent and fair, showing all documents by promising support and training to solve the problems that the factory may face, which results in long-term partnerships in return. In this case IntA's CompM explains “... we have a way to detect whether they have double book or not. Sometimes we will interview workers to check the working time and the income and how much income they get in one month and then we check the documents the factory shows us and we look if it is consistent or not...we will crosscheck with the factory management why there is a difference". As a result this triggers trustful relationships between the factory and the intermediary, which is mandatory for the factories to be open for any assessment at any time in order to win the big orders but also to be more powerful in discussing price and lead times, as FactC explains. Thus, trust and transparency is ensured by having full access to any factories' documents and managerial as well as workers' feedback at any time, but also through frequent meetings between the retailers and the intermediary, to exchange all necessary information about the supply chain. FactD states that trust was the most important factor in starting business with IntA and confirms "... we show our compliance documents what we have. Even if there are mistakes we don't hide anything, yes... they [IntA] are also trustful for us and we can work together...it comes from both sides" Interestingly, FactB reveals that trust emerges from the payment method i.e., the letter of credit (LC) IntA makes use of to pay for orders, as one of only two customers of the factory. Finally, FactB summarizes that in general social compliance can only exist if there is trust and reliability between the factory and its buyers. The geographical and cultural proximity between IntA and its factories turns out to be essential for building trust and long-term relationships, as it is possible to visit the factories any time for substantive dialogues and interviews, not only with managers but also with the workers in the production lines. RetA argues "...sometimes they [intermediaries] actually can have better relationships with the factories because they are on the ground... where we fall short they [intermediaries] actually help".

IntA's CM additionally explains their support to its factories "...we ensure and prepare, we continuously keep on working with our supplier base to keep on upgrading them and maintaining the social compliance". Hence, capacity building of the factory is significantly improved by the intermediary, especially through the direct and indirect supplier development strategies performed by IntA. This was proven by further statements and it turns out that there is a strikingly high demand for receiving support by the case factories to improve their social performance according to the apparel market's requirement, as three factory managers (FactB, FactC, and FactD) clearly explain. For instance, FactD acknowledges that "...our factory would like to work directly with the brands but the capacity isn't enough. If our factory is working directly with the brand the price would be higher and better for us. But we are limited and need to work with the agency". Indeed, as additionally evidenced by the documents, IntA is 
undertaking supportive actions, especially in ensuring compliance with required MSI standards by retailers by assisting in auditing and monitoring processes.

Interestingly, indirect supplier development is realized at very early stages, given the fact that IntA is conducting an informal technical (aiming at quality standards) and an informal social audit (aiming at social standards) with any factory who applies for becoming a part of its supplier base. For the social audit, the compliance team of IntA will send a so-called "initial audit checklist" to the applicant factory. The initial audit is a checklist developed by IntA's compliance team, which covers and includes the most common social requirements of the brands or retailers (based on their codes) and the most commonly used MSI standards, such as BSCI, Better Work, Sedex (Supplier Ethical Data Exchange), SA8000 and WRAP. Based on this document the factory evaluates itself and sends it back to IntA. In case the factory seems to be compliant, a first unannounced initial audit will be performed by the compliance team of IntA. Except for RetA, it is agreed by all case companies that there is no chance to become a member of the supplier base of IntA whenever a factory substantially fails the initial audit and shows no chance or willingness to improve in the near future to be compliant with the checklist in an announced re-audit. In case a factory does not hold the required MSI certification yet but is an appropriate candidate to fulfil the order based on lead times and quality, IntA sends its own compliance team to the potential factory to prepare them for the SA8000 (or any other MSI certification) or make them ready to pass the third party audit. The preparations include direct supplier development activities by IntA, such as support in organizing and managing the right documents and educating the factories' compliance team on how to improve current social issues and to be ready for any required third party audit for MSI accreditation. It is noteworthy that during this preparation time, which can last up to six months depending on the social issues (e.g., one manager states that payment rolls cannot be improved within a few days and takes time) the factory is already allowed to process the order. Ultimately, the factory receives the green light to call a third party auditor. Nonetheless, IntA decides whether it is worth it to work with the supplier until it is certified. IntA's QA/QC summarizes "when you go for any third party audit, the points they are going to find, we already know very well". Finally, RetA further describes the supportive auditing services, "The intermediary do like a checklist before. They do a sense check of very general things like if there is a young looking kid in a factory they will raise it to us...or they will ask for the paper work". In fact, factories underline their supportive role for any third party auditing. For example, FactA claims "... [IntA] sometimes supports the factory to go through the audit [third party audit for MSI standards] and remind the factory that they need to improve before the official third party audit from the buyer is conducted".

In the case where a factory has some violations according to the third party audit for MSI certification, the development of a CAP is the consequence. This was consistently confirmed by all case companies by showing the researchers actual and relevant $\mathrm{CAP}$ documents that underline that the corrective actions can be done very quickly or require more time, depending on the violations found in the audit report. In general, the CAP is always done by the factory with the support of IntA's compliance team in alignment with the third party auditor, who will send the CAP report to the retailer. However, from the factories' point of view, this is only true if the order is made via IntA. IntA's CompM states "We help the factory if there is any finding is not corrected in proper way. If there is any findings which we don't know how to correct it, we will discuss with buyer to find the best solution for both". Based on that, unannounced re-audits (or interchangeably used follow up audits) will be conducted to figure out whether improvements have been made. The first CAP is thus the starting point for any monitoring activity performed by IntA. Also, IntA conducts frequent visits to its factories, as they are spatially close to the factories and can be present on site to interview other compliance managers and check whether they can still keep up with the certification requirements. These frequent visits are especially done because once a factory successfully passes a third party audit it can take, depending on the MSI certification, up to three years until the next audit will be conducted to refresh its compliance status. In this regard, IntA will also be present when retailers go for their own assessment at the factory, 
thus taking over a supportive monitoring role as RetA states "... usually they [sourcing intermediaries] are present in assessments as well and any communication that we form with the factory as well".

In addition, all participants bring up the direct support they receive by organized workshops and training conducted by IntA, as this was further observable from documents such as the educational social compliance training presentations of the companies. The training also includes the retailers' training, who educate intermediaries about their latest requirements. In this case, RetA states "...we call it train the trainer... like I said we can't be at so many places at once. So we train the intermediaries". Additionally, evidence showed that IntA uses training not only for knowledge sharing but also to convince the factories to be socially responsible and make them understand why they should be compliant with the local labor law and that labor conditions can to a committed relationship between the factory workers and the factory management, which decreases fluctuation rates.

\subsubsection{Communication Strategies}

The previous section outlined that the exchange of information between the supply chain actors is critical, not only to generate trust but also to communicate in a clear and comprehensive way about all activities undertaken to ensure social sustainability, such as convincing factories about social compliance and ensuring full transparency to the retailers. This becomes particularly critical for the reports on compliance and standards to the retailer, such as through the "CSR Compliance Status Report", as IntA's CM declares. IntA organizes every document needed to provide the retailers with sufficient information, such as the factory's compliance status and its corrective action plan. As learned earlier, due to cultural differences the implementation process of social sustainability can be hampered. In this regard the case factories and RetA are aware that intermediaries in general have good opportunities to make business and refer to their linguistic capabilities. This was particularly confirmed by FactB, who stated that "Here [in Vietnam] the [factory] managers are local, they don't know English. They [IntA] also have many people go to see the factories and you can see in their company that mostly the managers are foreigners. Foreigners are better, they still have the mind-set how to work in the right way". This indicates that IntA, besides their linguistic capabilities, has a necessary cultural sensitivity towards both western countries, who demand social compliance, and the local factories, which is beneficial to convince the factory to embrace social sustainability and to trigger partnerships based on trust, as outlined earlier. IntA's CompM argues "Some factories don't know [... ] how and what the compliance in general is. So we will provide the training with the factory management to make them [factories] understand why factories should be compliant with the labor law with the labor conditions". In this regard FactA, Fact C and RetA explicitly explain that they are informed and updated by IntA about any social sustainability requirements. For example, FactA explains, "[IntA] will help the factory if there are any requirements from the buyer or any new requirement from the labor law, so they will support the factory for their awareness". Ultimately, RetA admits, "They [intermediaries] are very savoy in terms of every single requirement that was out there. Very up to date and many times we get updates on the local law by these agencies".

This critical knowledge transfer is enabled through, again, the geographical distance, as RetA pointed out earlier that the intermediary is on the ground. FactC asserts, "... they [IntA] just call us to come to their office" and a sensitive cultural understanding that considers morals and value systems are explained by each of IntA's Managers. According to the CM “... this [Vietnam] is just a country which is just free for 40 years now. Can a 40 years country compete with a country like America which is a 400 years country? Of course they [western countries] have prosperity, of course their value systems are different. So that's the typical dilemma. At this situation no Asian country wants to be taught by any western countries. They don't need a moral policy".

\section{Discussion}

Based on the analysis, this research first provided insight into why the case companies show responsibility towards social sustainability in Vietnam. Then, the findings depict, from the view of three supply chain actors, how the implementation of social sustainability is enabled trough the apparel 
sourcing intermediary, which gives a deeper understanding of the activities undertaken. Therefore, in this section, the researchers discuss the findings critically and describe the role of the sourcing apparel intermediary by integrating and organizing the social management strategies (activities) of each role, and hence answer RQ3.

First it is noteworthy that IntA is highly social sustainability oriented. The interviews with the managers of IntA showed high internal orientation towards sustainability issues, which is proposed by Köksal et al. [26] to be the most important enabler for social sustainability in the apparel supply chain. When focusing on the drivers for social sustainability, the role of NGOs have been discussed as the most significant pressures for apparel retailers to implement social risk management, especially by insisting on MSI standards and certifications to safeguard their business [12]. This pressure will be passed to the intermediary and hence will find its way to the factories. Further, it is clear, as Stigzelius and Mark-Herbert [65] observe, that the financial risk for factories deriving from the implementation of social sustainability needs to be balanced with higher prices or continued business. In fact, it is striking that the case factories based in Vietnam do not see financial risks associated with the implementation of social sustainability but rather see them as an investment, and thus as a driver to get big orders, form long-term partnerships, and keep their skilled workers. This is particularly interesting because researchers in previous studies repeatedly evaluated the implementation process and its related costs as a highly hindering factor for apparel factories in other developing countries $[26,37,38,65]$. Further and contrary to other researchers $[12,38,61,65,111]$, governmental pressure is perceived as a crucial driver for Vietnamese suppliers. This was explained by the Rana Plaza incident, which caused huge pressure and, as a result of the imminent trade war between the USA and China, enabled the chance for Vietnam to boost its exports for textiles and apparel [112-114].

In understanding the drivers for Vietnamese suppliers, first the researchers were able to get an overall picture of the social management activities performed by IntA, especially how they can leverage the implementation of social sustainability in ways where apparel retailers may fall short. As a result, it turned out that IntA clearly acts as an enabler in the social sustainability implementation process. The cases demonstrate that apparel retailers shift social responsibility to a large extent to the intermediary. This generally confirms the findings of Masson et al. [1], who conclude that retailers pass responsibility to intermediaries to mitigate and manage typical supply chain complexities [1], however, this study shows that social sustainability issues need to be considered and should not be excluded from an intermediary's responsibilities. From the researchers' analysis of social management strategies in Section 4.2, it has been demonstrated how IntA makes use of its capabilities to facilitate supplier development-, compliance-, and communication strategies. For instance, evidence shows that spatial proximity, with its capabilities in the form of multinational compliance and technical management teams, are fruitful for supplier development strategies in order to ensure that the factories in their supplier base are compliant with the social or ethical standards demanded by the apparel retailers. Consequently, IntA provides benefit to both supply chain actors i.e., the retailers and the factories they are working with. This is in contrast to suggestions of other researchers on sustainable supply chain theory, who argue that the longer a supply chain, the more vulnerable it becomes in terms of sustainability, and this is due to a lack of transparency and thus impedes, from the retailers point of view, the build up of necessary close collaborations with the factories $[1,14,26]$. To the contrary, the paper at hand depicts the critical activities that the sourcing intermediary performs in implementing social sustainability, although the supply chain is extended with an additional actor and thus they disconnect the apparel retailer from the apparel factories.

In order to answer the third research question, this study attempts to describe the roles performed by IntA by using role theory in supply chain management research [115]. Role theory was applied by several researchers to explore and describe the activities of the boundary-spanners within the supply chain networks [7,85,86,115-118]. Knight and Harland [115] reviewed existing constructs with regards to role theory and assess that it is beneficial for analyzing what part a focal company plays in the supply chain network. Therefore, role theory helps to interpret the findings and serves as the base for 
the formulation of research propositions that are to date, and to the best of the researcher's knowledge, not explored by any other academic researcher with regards to the social sustainability activities of apparel intermediaries. For example, Jia et al. [88] conducted role theory to interpret the roles played by IPOs. Their study is therefore used as a guideline and, consequently, highly interesting linkages emerged as the sourcing intermediary can be comprehensively described by applying role theory. By applying role theory, the inductive findings (the social sustainability roles and activities performed by the independent apparel sourcing intermediary (IntA)) are depicted in Table A2 and help to refine and extend the existing SSCM theoretical frameworks outlined in the literature review.

\subsection{Social Sustainability Supplier Developer and Coordinator}

As the literature review highlights, establishing trustful collaborative relationships will lead to the increased adoption of social compliance strategies and support the social sustainability process within the supply chain significantly $[14,27,36,81,82]$. Such collaborative relationships are shaped by supplier development strategies practices by focal companies [82], which ultimately evoke trust and commitment [36]. In general, researchers agree that trust and commitment facilitated within a collaborative relationship have significant effects on the improvement of CSR related activities and the willingness to conform with social responsibility requirements $[27,41,49,58,62,81,83]$. With regards to role theory, Jia et al [88] defines the supplier developer role as activities which educate, train, and support suppliers. Evidence shows that IntA plays a critical role in educating and convincing factories with sound quality and lead time performances to be socially compliant. This educational and convincing approach not only opens the eyes of its supplier base and significantly increases their awareness for social sustainability but also develops trust and transparency between the two supply chain actors. In this regard, direct and indirect support is provided by IntA and understood as a natural service. Particularly, IntA's proximity to the local factories and its specialized compliance team enables constant dialogues and updates and finally upgrades factories through monitoring activities, workshops and trainings. Starting with an initial, informal audit IntA is able to evaluate a factories social compliance potential. IntA then prepares the factory through respective corrective action plans until it finds the status to be ready for social MSI accreditation with third party audits. During the whole process the intermediary accompanies and monitors the factory and simultaneously reports progresses made to the retailer who requires a certain social MSI standard. Again, IntA continuously executes supplier development strategies, also after factories achieved MSI accreditation. Therefore, the first proposition can be developed:

- P1: Due to its supplier developer role the social sustainability oriented sourcing intermediary significantly enables the implementation of social sustainability in alignment with apparel retailers' required social MSI standards and certifications.

Moreover, Jia et al. [88] define that the coordinating role of IPOs involves "the development of a collaborative trust relationship with local suppliers". The support and visibility to the market a factory gains through the intermediary builds up trust between the two actors, which ultimately results in collaborative partnerships. As this study findings show, the coordinator role can only be realized if the supplier-developer role is active in advance. Hence, it seems that in social sustainability supply chain research, the two roles are not mutually exclusive but rather cohesive, and sequential progress is necessary. Furthermore, due to its capabilities, IntA receives high levels of responsibility and is thus perceived as an extension of the retailers who are characterized by trust and transparency. This leads to the following, second proposition:

- P2: As a result of its supplier development strategies, the social sustainability oriented sourcing intermediary is able to perform the coordinator role, which develops trustful and collaborative relationships with its supplier base and consequently with apparel retailers. 


\subsection{Social Sustainability Gatekeeper and Safeguard}

Based on the definition of Hallenbeck et al. [119] the gatekeeper collects, filters, and transmits information concerning actual and potential suppliers. This involves the activities of identifying new suppliers, but also auditing and quality control [119]. Other researchers use the term information broker, which involves the same activities [115]. In this context possible issues that arise in the buyer-supplier relationship include a lack of knowledge regarding sustainability issues, which has been declared to be a barrier in establishing a collaborative relationship [62] between the western apparel retailer and the developing country apparel factory. This again is attributable to the cultural, as well as the spatial distance between the two actors [57,79] and remains a highly difficult task, especially due to resource intensive investments such as setting up IPOs or subsidiaries in the respective supplier country. Thus, Oelze [62] suggests that knowledge gaps can be bridged by hiring intermediaries. In effect, IntA transmits any new requirements set by the retailers to the factories but also educates retailers about new or upcoming governmental regulations. The workshops and trainings provided by the retailers serve as a platform of knowledge exchange for social sustainability between retailers and IntA. Subsequently, the knowledge and critical information collected by IntA is passed on to the factories, again via workshops and training, but also through frequent meetings with factory managers on the spot. This ultimately supports the communication of social sustainability concerns between retailers and factories. More specifically, IntA facilitates the buyer-supplier relationship and informs apparel retailers via documents and reports especially about the actual state of the social sustainability status of the factories. Through initial audits, monitoring activities via frequent visits, developing supplier base compliance status documents, backing the factories during third party audits, providing corrective action plan support to the factories, and finally transparent communication with the factories ensures trust is strengthened significantly $[63,78]$ and the knowledge gaps between the apparel retailers and the factories are substantially reduced because IntA is up to date concerning any factory. Again, all the collected information about social sustainability concerns at the factories site is documented and reported and remain at the ready any time for apparel retailers.

- P3: The social sustainability oriented sourcing intermediary is the most critical facilitator in communicating social requirements to the respective apparel supply chain actors.

- P4: The social sustainability oriented sourcing intermediary is the most critical facilitator in communicating actual social sustainability status of factories to apparel retailers.

Moreover, and different to Jia et al. [88], it is crucial to take note that IntA, in its gatekeeping role, needs to be evaluated from two perspectives: the retailers' and factories' view as learned above. In addition, it seems that merely focusing on information and knowledge exchange is not sufficient to enact the gatekeeper role. More specifically, apparel retailers benefit from the intermediaries' socially compliant supplier base. Moreover, the cases show that social responsibility is shifted to the intermediary, which is consistent with findings of Masson et al. [1] and Neu et al. [33]. For example, Masson et al. [1] revealed that retailers showed little to no evidence of a relationship with the garment manufacturer, which hugely hinders any social management strategy. Therefore, the high dependency of western retailers on intermediaries located in developing countries is the result. Researchers claim that this causes high risk for the retailer, due to the lack of control and transparency [1]. In fact, based on the interviews and documents, the shift of social responsibility was observable.

- P5: Apparel retailers pass on social responsibility, thus transferring social management strategies to intermediaries when sourcing from developing countries.

In sum, IntA is able to assess and communicate the actual social compliance status of any existing factory in its supplier base but also can identify new factories with high social compliance potential. Hence, it turns out that the gatekeeper role needs to be extended with another activity so far not considered by researchers. Especially due to IntA's compliance team conducting initial audits, which 
cover the most significant requirements of MSI certifications, the intermediary serves with chosen factories and shows high tendencies to be socially compliant to the respective apparel retailers' requirements. This filtering activity safeguards the development of a social sustainable supply chain and leverages the typical risks that can emerge due to distance and cultural differences.

- P6: The social sustainability oriented sourcing intermediary acts a social sustainability safeguard for apparel retailers by presenting a socially responsible supplier base or at least high potential socially responsible factories.

On the other hand, all of the factories in its supplier base benefit from the access and visibility provided through the intermediary. This finding supports previous research on intermediaries [15]. However, the factories face enormous advantages, which makes it highly attractive to do business with a local intermediary. Most prominently, the intermediary is perceived as a channel to the western market, especially for factories without sufficient resources and capabilities for a well-connected, western thinking merchandise team, which includes cultural sensitivity or knowledge and understanding about western retailers' current social requirements. In fact, it is striking that all the Vietnamese case factories' managers are mostly locals with a very local mind-set who lack the sophisticated channels and network to access the western market. This was especially observable during the interviews, as the case factories' managers lacked English language skills and the compliance managers of the factories merely took on simple executing roles to ensure social compliance. With consideration of the very basic requirements for social compliance of western retailers, factories can show up much easier and enhance their visibility via intermediaries without concentrating their resources on merchandise and marketing capacities [15]. Thus, the following proposition can be developed:

- P7: The social sustainability oriented sourcing intermediary acts as a significant enabler for developing country apparel factories to achieve business eligibility and visibility based on apparel markets' social sustainability requirements.

\subsection{Cultural Broker}

Previous research stresses the fact that communication and comprehension issues between western retailers and developing country factories will hinder supplier development strategies and social sustainability implementation [57,73,79,80]. As found by Busse et al. [79], spatial distance, linguistic distance, and cultural distance are major antecedents. Ciliberti et al. [80] reveal that companies face huge barriers with the integration of CSR in developing countries, especially due to communication gaps and a lack of information, which stem from cultural and linguistic distance. Moreover, Awayshe and Klassen [57] confirmed that the spatial distance problematic is especially affecting communication efforts, such as the documentation of social audits and compliance. Other research supports and point at geographical and cultural distance both affecting the development of trustful strategic supply chain partnerships [58,84]. In other words, as distance in culture, including language and location is increasing, supply chain actors need to make sure that western based codes are comprehensive in their meaning and their application to be actionable [73]. The findings in the study at hand show that IntA is able to overcome and leverage spatial, cultural and linguistic distance in contrast to a direct retailer-factory relationship. In sum, the cultural broker role shows a particularly beneficial presence in each of the social management strategies previously outlined. However, the greatest advantage of IntA is its spatial proximity to its factories and its cultural understanding towards the westerners and the Vietnamese. Equipped with a compliance and merchandise team consisting of multinational managers who are familiar with both the western and Vietnamese culture, they leverage and significantly mitigate linguistic and cultural misalignments between apparel retailers and factories. Each of the social management strategies highly benefit from this capability and it turns out to be fundamental for effective supplier development and supply chain communication. Hence the following proposition can be developed: 
- P8: The social sustainability oriented sourcing intermediary significantly reduces cultural tension between western retailers and developing country factories and ultimately enhances supplier development and communication strategies within the apparel supply chain.

\subsection{Social Risk Manager}

Finally, a new role has emerged for the apparel intermediary. As a gatekeeper and with its safeguarding role the intermediary also assumes some risks whenever violations or social issues appear in its supplier base. For example, Neu et al. [33] discuss how production risks will be transferred to intermediaries via written contracts. In the case of failing the contract requirements, where financial penalty is incurred due to retailer allegations, the IntA takes on further risk. Thus, in the context of social sustainability, the IntA takes over any additional social risk $[12,26]$. Thus social responsibility is transferred by the apparel retailers to the intermediary, as evidenced by the interviewees. Additionally, Int A contracts with factories by letter of credit payments that signify whenever an apparel retailer is not able to pay for the orders, regardless of any payment defaults that occur, the factories are secure. Moreover, despite the dependency of Vietnamese factories' to find business with western retailers through IntA, very interestingly each of the case factories pointed out that they want to avoid any work with intermediaries, but would rather directly do business with the retailers. This was explained by the decreasing profits of the case factories when working with intermediaries. Hence this turns out to be a possible risk for IntA, because once factories are upgraded, have found maturity in ensuring social compliance, and are well connected with western retailers, they could have the chance to dissolve working with the intermediaries and realize better prices with direct contracts to apparel retailers. As such, with IntA's investments to a factory, especially considering transaction costs for supplier development strategies, high risks can emerge $[120,121]$ and new factories with potential investments for social sustainability improvements need to be considered to fulfil future orders.

- P9: Due to its gatekeeping and safeguarding role, the social sustainability oriented sourcing intermediary assumes high social management risks.

- P10: The social sustainability oriented sourcing intermediary assumes high risk in securing and developing capabilities for the apparel factories, which can leave them once a factory finds business maturity and is visible to the markets, thus contracting directly with apparel retailers.

\section{Conclusions and Implications}

In this paper the researchers first depict comprehensively why Vietnamese apparel suppliers, including sourcing intermediaries and factories, are motivated to embrace social responsibility. This was particularly helpful not only to understand their drivers, but also to dig deep into their interaction and to understand how the actors manage social sustainability. In addition, this paper strived to exclusively focus on the role played by the apparel sourcing intermediary in managing social sustainability. Based on the findings and analysis, ten propositions have been developed, all explicitly concentrating on the apparel intermediary's roles as an enabler for social sustainability in apparel supply chains. These roles are social sustainability supplier developer and coordinator, social sustainability gatekeeper and safeguard, social sustainability cultural broker, and social risk manager.

Interestingly a socially oriented third party indirect sourcing intermediary not only adds value in order to achieve better prices, quality and lead times for apparel retailers, but also acts as a social sustainability manager, which is a novel contribution to the debate. It is noteworthy to outline that the case apparel intermediary in this study is not promoting itself as a sustainable company, but rather provides social sustainability as a natural service, which is primarily shaped by the top management social responsibility orientation [26]. Starting with its cultural broker role, each of the sourcing intermediary's social management strategies enormously benefit from its spatial proximity to the factories, but more importantly, from the cultural sensitivity in understanding both the Western and Asian cultures. First, it turned out that the intermediary's supplier developing and coordinating 
roles are the most important for establishing trustful and collaborative relationships to all of its factories in its supply base. This in particular highly contributes to a successful social sustainability implementation process, which is of high interest for apparel retailers. Second, an independent sourcing intermediary can leverage any communication issues between apparel retailers and factories, especially by successfully channeling social sustainability information, such as educating about the actual requirements or informing on the reports and documents available to the respective supply chain actors. Consequently, an intermediary can act as a gatekeeper who can be specified as a filter for providing only socially compliant or at least highly potential factories to its customers, the apparel retailers. These findings further indicate that social management strategies traditionally conducted by apparel retailers will be transferred to the intermediary and with it the responsibility to ensure a socially sustainable supply chain. In this regard, from the apparel retailers' point of view, the intermediary can be described as a safeguard for a socially responsible supply chain. As a consequence, due to the shift of social responsibility but also especially in performing supplier developer strategies, the apparel sourcing intermediary takes over the role of a social risk manager, as learned during the analysis.

\subsection{Theoretical Implications}

This research highly contributes to existing sustainable supply chain research in a number of ways. First it focuses on two neglected areas, the social dimension of sustainability [26-28] and the lack of research on apparel sourcing intermediaries [6,55]. Moreover, it concentrates on supply chain research in a developing country, which still falls too short in the sustainability debate [26-28,38,49]. Finally, as recommended by previous researchers $[55,97]$, this study explores the role of the intermediary, with insights from more than one sustainable supply chain actor and includes three stages: the apparel retailer, sourcing intermediary, and factory views for exploration. Thus, this paper is, to the best of the researchers' knowledge, the first of its kind to investigate the role played by an apparel intermediary in accordance to its social sustainability activities. The study at hand further extends the role theory with the incorporation of an independent apparel sourcing intermediary and its overdue focus on social responsibility and additionally supports previously developed frameworks to the social sustainability supply chain, such as Köksal et al. [26], by integrating new insights into the model. Further, the researchers give evidence of a real life situation that each social management strategy is not exclusive and dependent from each other as assumed by Yawar and Seuring [27]. Additionally, the findings highly contribute to the literature with the apparel intermediaries' roles facilitating and ensuring trust and transparency among the supply chain actors, as suggested by Yawar and Seuring [27], who state that future investigations should "focus on the ways to reduce trust deficiencies among supply chain members to achieve a socially sustainable supply chain". Lastly, this study follows recent propositions of Nakamba et al. [19] and Huq et al. [49] in exploring multi-tier supplier perspectives towards the implementation of social sustainability practices in developing countries.

\subsection{Managerial Implications}

From the perspective of management, it is suggested that apparel intermediaries should not only focus on delivering the best price, quality, and lead time possible, but rather need to incorporate social responsibility in their overall strategy as their customers i.e., apparel retailers see social compliance in their sourcing strategy as the minimum mandatory requirement before orders will be placed. Therefore, building up a multinational compliance management team that is familiar with both the local as well as the western culture and language is critical for international apparel intermediaries in order to be able to perform the outlined social sustainability roles successfully and increase competitiveness through differentiation. Again, it is important to highlight that each supply chain actor needs to show the willingness to be socially compliant and requires high degrees of trust, credibility, and transparency. What remains are the risks for the apparel retailer to be spotlighted once critical violations, such as child labor, occur in the supply chain. However, this paper clearly supports the CSR and the sourcing departments' decision making of any apparel retailer sourcing from developing countries. 
Furthermore, this study depicts how critical it is to source from the "right" intermediary with regards to sustainability and the economic advantages an apparel retailer gains through mediated sourcing, Huge parts of CSR related activities can be leveraged and enabled by socially oriented sourcing intermediaries, which can save costs, time, and reduce the information asymmetries and ultimately mitigate social risk. More specifically, developing a trustful partnership and collaboration with one socially oriented apparel intermediary might be the more efficient approach compared to establishing trustful partnerships to multiple factories. Therefore, redundancy for any social management strategy can be reduced or even removed. Hence apparel retailers can concentrate on core business activities and allocate its resources to other departments. Most importantly, the outlined propositions of this study can be used by decision makers in the apparel industry as a guideline, especially those who still face problems with social sustainability implementation or need support with intermediary selection in developing countries. For example, apparel retailers can use the outlined roles and their underlying activities to rethink their strategic activities and to crosscheck and evaluate the roles of yet existing or future intermediaries in its supply chain. From the apparel factories' view the right sourcing intermediary is not only the gate keeper to big orders from apparel retailers but also a great opportunity to upgrade its own facility and operations with regards to social responsibility. This ultimately makes the factory more competitive and increases the longevity of its business through an enhanced image and reputation in the apparel market.

\subsection{Limitations and Future Research Directions}

First, as the researchers conducted multiple-case studies and qualitative analyses, the sample size of this research is limited and hence its generalizability to all apparel sourcing intermediaries in developing countries is also limited. This study only concentrates on the role of one apparel intermediary located in Vietnam, which in addition shows a high social sustainability orientation. Thus, it seems that the study at hand tends to be a best practice evaluation and it is very likely that not all intermediaries show a high internal orientation towards social sustainability. Consequently, this study is limited in its representativeness and hence does not allow generalizing to other independent apparel intermediaries in developing countries. Moreover, as different industries have different characteristics in their supply chains, the findings of the paper at hand are not applicable to other sectors. As such, do other apparel intermediaries in developing countries assume social sustainability roles? How and to what extent do other intermediaries in developing countries enable social management strategies?

This is the first attempt to apply boundary-spanning role theory on the apparel sourcing intermediary in order to describe its activities for social sustainability. In fact, the social sustainability roles found in this study need to be sharpened and more clearly distinguished from each other, which opens new directions for future research. Especially because this study shows that the underlying activities in each social sustainability role are not mutually exclusive. Yet, the existing role theories on boundary-spanners were sufficient to get a first comprehensive picture. Therefore, academics may replicate the study at hand in order to investigate the role of the apparel intermediary in other developing countries and in other industries. For instance, it turned out that supplier development strategies are highly critical in establishing trust and transparency related to the coordinator role. Moreover, do the underlying, resource intensive activities always pay out for the intermediary?

Furthermore, the results only focus on its enabling role. The barriers to the implementation process need further investigation and remain unclear because this study gives clear indications that hindering factors are likely to occur. Thus, what barriers typically emerge for social sustainability in developing countries when apparel intermediaries are hired? Based on this, researchers should include further views on intermediaries and may investigate the perceptions of NGOs or third party auditors, but more critically, factory workers. For example, only the managers of the case companies were interviewed, which might generate biased conclusions. Factory workers were not considered and no social sustainability performance measurement was undertaken, keeping the effectiveness of the intermediaries' enabling role vague, which calls for future investigation. Further examples highlight 
that MSI certifications are merely instrumentally used $[26,29,38,42,61,63,68]$, as two cases gave hints that they are all "almost the same" and easy pass once a factory holds one MSI certificate. In addition, as evidenced by two cases it seems that also the Vietnamese government conducts social audits but are prone bribery. Based on the findings and propositions in this study, it turned out that between the factories and the intermediaries, different interests for the implementation of social sustainability exist and thus this opens the door for the application of other in SSCM neglected theories [19], such as principal-agent or transaction cost theory, to get another angle on their interaction and understand the SSCM actors relationships more clearly. For example, by considering the social risk manager role, it seems that the intermediary is socially oriented, whereas the factories show social responsibility and the willingness to invest only for economic reasons and actually want to avoid working with intermediaries. Lastly, this research stream calls for a deeper investigation of subcontractors. From the interviews it turned out that subcontractors still remain obscure and are not covered by the retailers' required MSI certification automatically. While required social standards and certification systems may cover Tier 1 factories, the subcontractors, which represent a further tier, remain uncovered and thus are likely the reason for social violations in the apparel supply chains as transparency and control decreases. Hence, the question arises how far the social sustainability roles performed by the apparel intermediary can go in the supply chain, and whether they can open new research avenues, which will extend the dominant frameworks on social SSCM.

Acknowledgments: We are very thankful that this research has been supported by the School of Textiles \& Design of the Reutlingen University (Germany) and that the article processing charge was kindly funded by the Baden-Württemberg Ministry of Science, Research and Culture in the funding program Open Access Publishing.

Author Contributions: Deniz Köksal designed, drafted, and wrote the entire manuscript and was responsible for the collection of the data and analysis. Jochen Strähle assisted with the case analysis during the coding process and Martin Müller critically revised the final manuscript.

Conflicts of Interest: The authors declare no conflict of interest. 


\section{Appendix A}

Table A1. Case Company Profiles.

\begin{tabular}{|c|c|c|c|c|c|c|c|}
\hline $\begin{array}{l}\text { Apparel } \\
\text { Supply } \\
\text { Chain Actor }\end{array}$ & Codes & Interviewee(s) & Product Categories & $\begin{array}{c}\text { Company } \\
\text { Size/Employees }\end{array}$ & Pieces Per Month & $\begin{array}{l}\text { Country Origin of Major } \\
\text { Customers (Brand Examples) }\end{array}$ & Compliance/Accreditition \\
\hline Retailer & RetA & Senior CR Coordinator & $\begin{array}{l}\text { Mens's and women's apparel } \\
\text { including e.g. jeanswear, } \\
\text { accessories, swimwear, } \\
\text { underwear, outerwear, } \\
\text { performance wear, footwear, } \\
\text { dresses, suits etc.. }\end{array}$ & approx. 15000 & - & - & $\begin{array}{l}\text { Companies own Code of } \\
\text { Conducts, Better Work, FLA }\end{array}$ \\
\hline Intermediary & IntA & $\begin{array}{c}\text { Country Manager } \\
\text { (CM); Compliance } \\
\text { Manager (CompM); } \\
\text { Head-QA/QC \& } \\
\text { Technical (QA/QC) }\end{array}$ & $\begin{array}{c}\text { Circular knits (T-Shirts, Polo } \\
\text { Shirts, Sweatshirts), } \\
\text { Coordinates, Denim, Dresses, } \\
\text { Flat Weave Bottoms (Chinos, } \\
\text { Cargo Pants, 5-Pocket Pants, } \\
\text { Skirts), Indoor Jackets, Men's } \\
\text { Shirts, Outdoor Jackets }\end{array}$ & approx. 150 & - & $\begin{array}{l}\text { USA and Europe (Abercrombie \& } \\
\text { Fitch, PVH Corp., Fillipa K., Pepe } \\
\text { Jeans, Marc o' Polo, True Religion, } \\
\text { Tom Tailor, Urban Outfitters etc.) }\end{array}$ & - \\
\hline Factory & FactA & Compliance Manager & $\begin{array}{l}\text { Fleece, Pants, Shirts, Blazers, } \\
\text { Jackets }\end{array}$ & approx. 1700 & 300.000 & Europe (Otto Group) & SA8000 \\
\hline Factory & FactB & $\begin{array}{l}\text { Head of R\&D; } \\
\text { Compliance Manager }\end{array}$ & $\begin{array}{c}\text { Jeans, non-Denim pants, } \\
\text { Chinos, Skirts, Dresses, Jackets, } \\
\text { Shirts }\end{array}$ & approx. 1800 & $\begin{array}{c}405600 \text { (sewing); } \\
1.000 .000 \text { (wash); } \\
500.000 \text { (dying); } \\
100.000 \text { (laser print) }\end{array}$ & $\begin{array}{l}\text { USA, Europe, Asia (True Religion, } \\
\text { Urban Outfitters, American Eagle } \\
\text { Outfitters; Dynamite, Tom Tailor, } \\
\text { Tommy Hilfiger, Walmart, Levis, } \\
\text { Express, Uniqlo, DKNY, Burberry, } \\
\text { Forever } 21 \text { etc.) }\end{array}$ & $\begin{array}{l}\text { VF (LEE), BetterWork, BSCI, } \\
\text { SEDEX, PVH (Tommy } \\
\text { Hilfiger), A\&F, SA }\end{array}$ \\
\hline Factory & FactC & Compliance Manager & $\begin{array}{c}\text { Blazers, Coats, Dresses, Blouses, } \\
\text { Pants, Jackets }\end{array}$ & approx. 3300 & 500.000 & $\begin{array}{l}\text { USA and Europe (Express, BCBG, } \\
\text { Chaus, Tesco, Tom Tailor, Primark, } \\
\text { New Look etc.) }\end{array}$ & Sedex, SA8000, BetterWork \\
\hline Factory & FactD & $\begin{array}{l}\text { Compliance Manager; } \\
\text { Vice Director; } \\
\text { Merchandise Manager }\end{array}$ & Dresses, Blouses, Coats, Jackets & approx. 1600 & $300.000-350.000$ & $\begin{array}{l}\text { USA and Europe (Tom Tailor, } \\
\text { Woolworth, Express, Chicos, } \\
\text { Tommy Hilfiger, Calvin Klein etc.) }\end{array}$ & Sedex, BSCI \\
\hline
\end{tabular}


Table A2. Social sustainability roles and activities performed by the independent apparel sourcing intermediary.

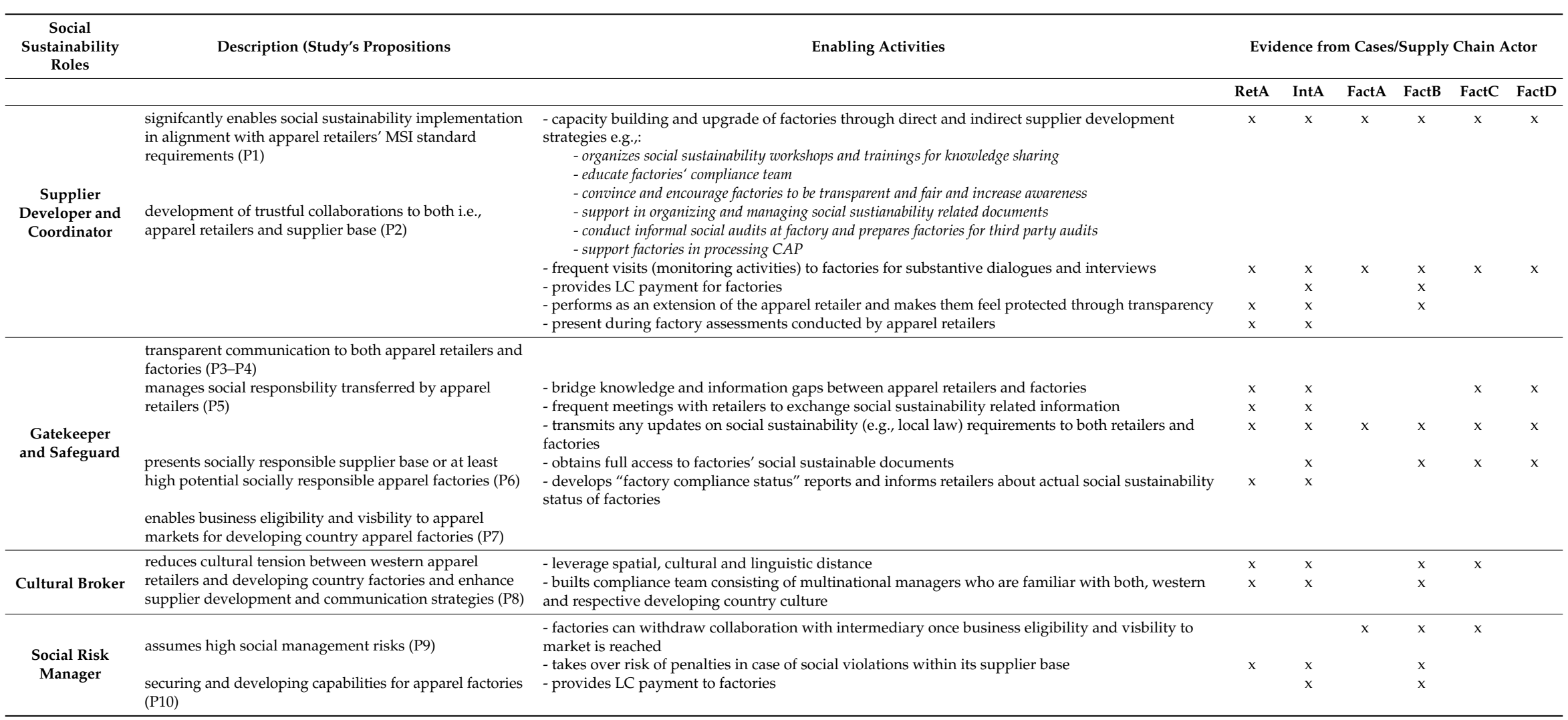




\section{Appendix B. General Interview Guidelines}

Apparel Sourcing Intermediary Interview Guideline:

- Do you consider yourself a full-package provider, sourcing agency or sourcing intermediary?

- How do you choose the right supplier for an order?

- Do you think western retailers do a better job in ensuring social compliance in their supply chains by employing sourcing intermediaries/agencies?

- What are possible social issues you may face in Vietnamese apparel supply chains?

- Why and how do you address social issues generally in your supply chain?

- How do you communicate legitimacy and accountability to your company's socially responsible behaviour?

- Do you have supplier development or collaboration strategies to improve your supplier base' social performance?

- Very generally, in terms of social sustainability, how should the apparel industry may change to improve its social responsibility? What are your advices to the industry?

Factory Interview Guideline:

- Who are your main customers and where are they located typically?

- Why do you choose the work with sourcing agents/intermediaries?

- What are possible social issues you may face in Vietnamese apparel supply chains?

- Do you think western retailers do a better job in ensuring social compliance in their supply chains by employing sourcing intermediaries/agencies?

- Why and how do you address social issues generally in your factory and further upstream in the supply chain?

- How do you communicate legitimacy and accountability to your factory's socially responsible behaviour?

- Do you receive supplier development or collaboration strategies to improve your factory's social performance?

- Very generally, in terms of social sustainability, how should the apparel industry may change to improve its social responsibility? What are your advices to the industry?

Retailer Interview Guideline:

- Why is it important for you to be engaged with social sustainability and require social compliance?

- Do you think you can do a better job in ensuring social compliance in your supply chain by employing sourcing intermediaries/agencies?

- What are possible social issues you may face in Vietnam?

- How do you address social issues when sourcing through third party intermediaries? What is the process behind looking like?

- How do you communicate about social requirements with the factories when sourcing intermediaries are in between?

- Do you have supplier development or collaboration strategies to improve your supplier base' social performance when working with intermediaries?

- Is the intermediary a good opportunity for you to ensure social compliance?

- Very generally, in terms of social sustainability, how should the apparel industry may change to improve its social responsibility? What are your advices to the industry?

\section{References}

1. Masson, R.; Iosif, L.; MacKerron, G.; Fernie, J. Managing complexity in agile global fashion industry supply chains. Int. J. Logist. Manag. 2007, 18, 238-254. [CrossRef] 
2. Ashby, A.; Smith, M.; Shand, R. From principle to Practice-Embedding sustainability in clothing supply chain strategies. In Sustainability in Fashion and Textiles: Values, Design, Production and Consumption; Gardetti, M.A., Torres, A.L., Eds.; Greenleaf Publishing Limited: Sheffield, UK, 2013; p. 72. ISBN 978-1-906093-78-5.

3. Kunz, G.I.; Karpova, E.; Garner, M.B. Going Global: The Textile and Apparel Industry, 3 ed.; Fairchild Books: New York, NY, USA, 2016; ISBN 978-1-5013-0730-0.

4. Bergvall-Forsberg, J.; Towers, N. Creating agile supply networks in the fashion industry: A pilot study of the European textile and clothing industry. J. Text. Inst. 2007, 98, 377-386. [CrossRef]

5. Cammett, M. Development and the Changing Dynamics of Global Production: Global Value Chains and Local Clusters in Apparel Manufacturing; Social Science Research Network: Rochester, NY, USA, 2006.

6. Cook, C.N.; Kozar, J.M. The Competitive Advantages of Sourcing Agents in Global Apparel Supply Chains: An Exploratory Study. In The Customer is NOT Always Right? Marketing Orientations in a Dynamic Business World; Springer: Cham, Switzerland, 2017; pp. 86-95.

7. Jia, F.; Lamming, R.; Sartor, M.; Orzes, G.; Nassimbeni, G. Global purchasing strategy and International Purchasing Offices: Evidence from case studies. Int. J. Prod. Econ. 2014, 154, 284-298. [CrossRef]

8. Allwood, J.M. Well Dressed?: The Present and Future Sustainability of Clothing and Textiles in the United Kingdom; Univ. of Cambridge Inst. for Manufacturing: Canbridge, UK, 2006; ISBN 978-1-902546-52-0.

9. Cattermole, A. Transparency is the New Green. AATCC Rev. 2016, 16, 42. [CrossRef]

10. Christopher, M.; Lowson, R.; Peck, H. Creating agile supply chains in the fashion industry. Int. J. Retail Distrib. Manag. 2004, 32, 367-376. [CrossRef]

11. Dicken, P. Global Shift: Mapping the Changing Contours of the World Economy; SAGE Publications Ltd.: Thousand Oaks, CA, USA, 2007; ISBN 978-1-4129-2955-4.

12. Freise, M.; Seuring, S. Social and environmental risk management in supply chains: A survey in the clothing industry. Logist. Res. 2015, 8, 1-12. [CrossRef]

13. Mamic, I. Managing Global Supply Chain: The Sports Footwear, Apparel and Retail Sectors. J. Bus. Ethics 2005, 59, 81-100. [CrossRef]

14. Perry, P.; Towers, N. Conceptual framework development CSR implementation in fashion supply chains. Int. J. Phys. Distrib. Logist. Manag. 2013, 43, 478-501. [CrossRef]

15. Purvis, L.; Naim, M.M.; Towill, D. Intermediation in agile global fashion supply chains. Int. J. Eng. Sci. Technol. 2013, 5, 33-48. [CrossRef]

16. Seuring, S.; Müller, M. From a literature review to a conceptual framework for sustainable supply chain management. J. Clean. Prod. 2008, 16, 1699-1710. [CrossRef]

17. WCED Our Common Future. Chapter 2: Towards Sustainable Development-A/42/427 Annex, Chapter 2-UN Documents: Gathering a body of global agreements. Available online: http:/ / www.un-documents. net/ocf-02.htm (accessed on 12 March 2018).

18. European Commission Responsible business: A key to competitiveness—Growth—European Commission. Available online: https:/ / ec.europa.eu/growth/content/responsible-business-key-competitiveness-0_en (accessed on 12 March 2018).

19. Nakamba, C.C.; Chan, P.W.; Sharmina, M. How does social sustainability feature in studies of supply chain management? A review and research agenda. Supply Chain Manag. Int. J. 2017, 22, 522-541. [CrossRef]

20. Carter, C.R.; Rogers, D.S. A framework of sustainable supply chain management: Moving toward new theory. Int. J. Phys. Distrib. Logist. Manag. 2008, 38, 360-387. [CrossRef]

21. Elkington, J. Partnerships from cannibals with forks: The triple bottom line of 21st-century business. Environ. Qual. Manag. 1998, 8, 37-51. [CrossRef]

22. Liu, W.; Bai, E.; Liu, L.; Wei, W. A Framework of Sustainable Service Supply Chain Management: A Literature Review and Research Agenda. Sustainability 2017, 9, 421. [CrossRef]

23. Singh, A.; Trivedi, A. Sustainable green supply chain management: Trends and current practices. Compet. Rev. 2016, 26, 265-288. [CrossRef]

24. Centobelli, P.; Cerchione, R.; Esposito, E. Environmental Sustainability and Energy-Efficient Supply Chain Management: A Review of Research Trends and Proposed Guidelines. Energies 2018, 11, 275. [CrossRef]

25. Masi, D.; Day, S.; Godsell, J. Supply Chain Configurations in the Circular Economy: A Systematic Literature Review. Sustainability 2017, 9, 1602. [CrossRef]

26. Köksal, D.; Strähle, J.; Müller, M.; Freise, M. Social Sustainable Supply Chain Management in the Textile and Apparel Industry-A Literature Review. Sustainability 2017, 9, 100. [CrossRef] 
27. Yawar, S.A.; Seuring, S. Management of Social Issues in Supply Chains: A Literature Review Exploring Social Issues, Actions and Performance Outcomes. J. Bus. Ethics 2015, 141, 621-643. [CrossRef]

28. Zorzini, M.; Hendry, L.C.; Huq, F.A.; Stevenson, M. Socially responsible sourcing: Reviewing the literature and its use of theory. Int. J. Oper. Prod. Manag. 2015, 35, 60-109. [CrossRef]

29. Egels-Zandén, N.; Lindholm, H. Do codes of conduct improve worker rights in supply chains? A study of Fair Wear Foundation. J. Clean. Prod. 2015, 107, 31-40. [CrossRef]

30. Gereffi, G. International trade and industrial upgrading in the apparel commodity chain. J. Int. Econ. 1999, 48, 37-70. [CrossRef]

31. Jiang, B.; Talluri, S.; Yao, T. Improving supplier's situation through supplier cooperation: The case of Xintang jeans town. Int. J. Prod. Econ. 2012, 139, 431-437. [CrossRef]

32. Perry, P.; Wood, S.; Fernie, J. Corporate Social Responsibility in Garment Sourcing Networks: Factory Management Perspectives on Ethical Trade in Sri Lanka. J. Bus. Ethics 2015, 130, 737-752. [CrossRef]

33. Neu, D.; Rahaman, A.S.; Everett, J. Accounting and Sweatshops: Enabling Coordination and Control in Low-Price Apparel Production Chains. Contemp. Account. Res. 2014, 31, 322-346. [CrossRef]

34. Baskaran, V.; Nachiappan, S.; Rahman, S. Indian textile suppliers' sustainability evaluation using the grey approach. Int. J. Prod. Econ. 2012, 135, 647-658. [CrossRef]

35. Gardetti, M.A. Sustainability in Fashion and Textiles: Values, Design, Production and Consumption; Routledge: Sheffield, UK, 2013; ISBN 978-1-906093-78-5.

36. Locke, R.; Amengual, M.; Mangla, A. Virtue out of Necessity? Compliance, Commitment, and the Improvement of Labor Conditions in Global Supply Chains. Politics Soc. 2009, 37, 319. [CrossRef]

37. Yu, X. Impacts of Corporate Code of Conduct on Labor Standards: A Case Study of Reebok's Athletic Footwear Supplier Factory in China. J. Bus. Ethics 2008, 81, 513-529. [CrossRef]

38. Huq, F.A.; Stevenson, M.; Zorzini, M. Social sustainability in developing country suppliers an exploratory study in the ready made garments industry of Bangladesh. Int. J. Oper. Prod. Manag. 2014, 34, 610-638.

39. Crinis, V. Sweat or No Sweat: Foreign Workers in the Garment Industry in Malaysia. J. Contemp. Asia 2010, 40, 589-611. [CrossRef] [PubMed]

40. Powell, B. Meet the Old Sweatshops. Indep. Rev. 2014, 19, 109-122.

41. Locke, R.; Kochan, T.; Romis, M.; Qin, F. Beyond corporate codes of conduct: Work organization and labour standards at Nike's suppliers. Int. Labour Rev. 2007, 146, 21-40. [CrossRef]

42. Merk, J. Jumping Scale and Bridging Space in the Era of Corporate Social Responsibility: Cross-border labour struggles in the global garment industry. Third World Q. 2009, 30, 599-615. [CrossRef]

43. Anuradha, N. Fashion brands bring hand-washing but little else to India's garment workers, say critics. Available online: https://www.reuters.com/article/us-india-garments-labour/fashion-brandsbring-hand-washing-but-little-else-to-indias-garment-workers-say-critics-idUSKBN1A50H9 (accessed on 25 March 2018).

44. Howard, C. On Fashion Revolution Day, Ask The Important Question: Who Made My Clothes? Forbes.com 2015, 11, Business Source Complete, EBSCOhost, viewed 23 January 2018.

45. Lusher, A. Refugee children are "making Marks \& Spencer clothes.". Available online: https: / / www.independent.co.uk/news/child-labour-sweatshops-refugees-marks-and-spencerpanorama-clothes-sold-in-uk-britain-british-high-a7376706.html (accessed on 25 March 2018).

46. Manik, J.A.; Yardley, J.; Greenhouse, S. Outrage Builds after Collapse in Bangladesh. The New York Times, 25 April 2013.

47. Mayer, C.; Sorrel, L. H\&M in factory horror as workers endure "sweatshop conditions" making clothes including Beyonce's line. The Sun, 27 September 2016.

48. O'Connor, C. These Retailers Involved in Bangladesh Factory Disaster Have Yet to Compensate Victims. Available online: http:/ / www.forbes.com/sites/clareoconnor/2014/04/26/these-retailers-involved-inbangladesh-factory-disaster-have-yet-to-compensate-victims / (accessed on 16 April 2015).

49. Huq, F.A.; Chowdhury, I.N.; Klassen, R.D. Social management capabilities of multinational buying firms and their emerging market suppliers: An exploratory study of the clothing industry. J. Oper. Manag. 2016, 46, 19-37. [CrossRef]

50. Strähle, J.; Köksal, D. Impact of Brand- and Country Image on the Perception of Sustainability in the Fashion Business. Int. J. Bus. Commer. 2015, 5, 25-58.

51. Belavina, E.; Girotra, K. Sourcing through Intermediaries. INSEAD Work. Pap. Collect. 2010, 82, 1-44. 
52. Adida, E.; Bakshi, N.; DeMiguel, V. Sourcing through Intermediaries: The Role of Competition; History: London, UK, 2014.

53. Dyer, B.; Ha-Brookshire, J.E. Apparel import intermediaries' secrets to success: Redefining success in a hyper-dynamic environment. J. Fash. Mark. Manag. Int. J. 2008, 12, 51-67. [CrossRef]

54. Gupta, A.; Dasgupta, P. Association between Sourcing Issues and Logistics Performance Variables in Apparel Exports: An Empirical Analysis of Sourcing Intermediaries. In Global Business Transcendence: International Perspectives across Developed and Emerging Economies; Arora, A.S., McIntyre, J.R., Eds.; International Marketing and Management Research; Palgrave Macmillan US: New York, NY, USA, 2014; pp. 80-103. ISBN 978-1-349-48963-3.

55. Fung, P.K.O.; Chen, I.S.N.; Yip, L.S.C. Relationships and performance of trade intermediaries: An exploratory study. Eur. J. Mark. 2007, 41, 159-180. [CrossRef]

56. Yang, Z.; Babich, V. Does a Procurement Service Provider Generate Value for the Buyer Through Information About Supply Risks? Manag. Sci. 2015, 61, 979-998. [CrossRef]

57. Awaysheh, A.; Klassen, R.D. The impact of supply chain structure on the use of supplier socially responsible practices. Int. J. Oper. Prod. Manag. 2010, 30, 1246-1268. [CrossRef]

58. Grimm, J.H. Ensuring Sub-Suppliers' Compliance with Corporate Sustainability Standards in Supply Chains. In Supply Management Research; Advanced Studies in Supply Management; Springer Gabler: Wiesbaden, Germany, 2016; pp. 37-57. ISBN 978-3-658-08808-8.

59. Anner, M. Corporate Social Responsibility and Freedom of Association Rights: The Precarious Quest for Legitimacy and Control in Global Supply Chains. Politics Soc. 2012, 40, 609-644. [CrossRef]

60. Auchter, L. Supply chain responsibilities and the need for an integrative ethic Management in Emerging Economies. Int. J. Bus. Econ. Dev. 2015, 3, 31-46.

61. Hoang, D.; Jones, B. Why do corporate codes of conduct fail? Women workers and clothing supply chains in Vietnam. Glob. Soc. Policy 2012, 12, 67-85. [CrossRef]

62. Oelze, N. Sustainable Supply Chain Management Implementation-Enablers and Barriers in the Textile Industry. Sustainability 2017, 9, 1435. [CrossRef]

63. Locke, R.; Qin, F.; Brause, A. Does Monitoring Improve Labor Standards? Lessons from Nike. Ind. Labor Relat. Rev. 2007, 61, 3-31. [CrossRef]

64. Baskaran, V.; Nachiappan, S.; Rahman, S. Supplier assessment based on corporate social responsibility criteria in Indian automotive and textile industry sectors. Int. J. Sustain. Eng. 2011, 4, 359-369. [CrossRef]

65. Stigzelius, I.; Mark-Herbert, C. Tailoring corporate responsibility to suppliers: Managing SA8000 in Indian garment manufacturing. Scand. J. Manag. 2009, 25, 46-56. [CrossRef]

66. Iwanow, H.; McEachern, M.G.; Jeffrey, A. The influence of ethical trading policies on consumer apparel purchase decisions: A focus on The Gap Inc. Int. J. Retail Distrib. Manag. 2005, 33, 371-387. [CrossRef]

67. Ansett, S. Mind the Gap: A Journey to Sustainable Supply Chains. Empl. Responsib. Rights J. 2007, 19, $295-303$. [CrossRef]

68. Lueg, R.; Pedersen, M.M.; Clemmensen, S.N. The Role of Corporate Sustainability in a Low-Cost Business Model-A Case Study in the Scandinavian Fashion Industry. Bus. Strategy Environ. 2015, 24, 344-359. [CrossRef]

69. Dargusch, P.; Ward, A. Understanding Corporate Social Responsibility with the integration of Supply Chain Management in Outdoor Apparel Manufacturers in North America and Australia. Int. J. Bus. Manag. Sci. 2010, 3, 93-105.

70. Ciliberti, F.; de Groot, G.; de Haan, J.; Pontrandolfo, P. Codes to coordinate supply chains: SMEs' experiences with SA8000. Supply Chain Manag. Int. J. 2009, 14, 117-127. [CrossRef]

71. O'Rourke, D. Multi-stakeholder regulation: Privatizing or socializing global labor standards? World Dev. 2006, 34, 899-918. [CrossRef]

72. Milne, A.T.C.; Dickson, M.A.; Keene, K. Small Business Implementation of CSR for Fair Labor Association Accreditation. J. Corp. Citizsh. 2013, 2013, 38-52.

73. Ciliberti, F.; de Haan, J.; de Groot, G.; Pontrandolfo, P. CSR codes and the principal-agent problem in supply chains: Four case studies. J. Clean. Prod. 2011, 19, 885-894. [CrossRef]

74. Bhaduri, G.; Ha-Brookshire, J.E. Do Transparent Business Practices Pay? Exploration of Transparency and Consumer Purchase Intention. Cloth. Text. Res. J. 2011, 29, 135-150. [CrossRef] 
75. Burchielli, R.; Delaney, A.; Tate, J.; Coventry, K. The FairWear Campaign: An Ethical Network in the Australian Garment Industry. J. Bus. Ethics 2009, 90, 575-588. [CrossRef]

76. Kozlowski, A.; Searcy, C.; Bardecki, M. Corporate sustainability reporting in the apparel industry. Int. J. Product. Perform. Manag. 2015, 64, 377-397. [CrossRef]

77. Shaw, D.; Hogg, G.; Wilson, E.; Shui, E.; Hassan, L. Fashion victim: The impact of fair trade concerns on clothing choice. J. Strateg. Mark. 2006, 14, 427-440. [CrossRef]

78. Turker, D.; Altuntas, C. Sustainable supply chain management in the fast fashion industry: An analysis of corporate reports. Eur. Manag. J. 2014, 32, 837-849. [CrossRef]

79. Busse, C.; Schleper, M.C.; Niu, M.; Wagner, S.M. Supplier development for sustainability: Contextual barriers in global supply chains. Int. J. Phys. Distrib. Logist. Manag. 2016, 46, 442-468. [CrossRef]

80. Ciliberti, F.; Pontrandolfo, P.; Scozzi, B. Investigating corporate social responsibility in supply chains: A SME perspective. J. Clean. Prod. 2008, 16, 1579-1588. [CrossRef]

81. Gimenez, C.; Tachizawa, E.M. Extending sustainability to suppliers: A systematic literature review. Supply Chain Manag. Int. J. 2012, 17, 531-543. [CrossRef]

82. Sancha, C.; Gimenez, C.; Sierra, V.; Kazeminia, A. Does implementing social supplier development practices pay off? Supply Chain Manag. Int. J. 2015, 20, 389-403. [CrossRef]

83. Carter, C.R.; Jennings, M.M. Social responsibility and supply chain relationships. Transp. Res. Part E Logist. Transp. Rev. 2002, 38, 37-52. [CrossRef]

84. Grimm, J.H.; Hofstetter, J.S.; Sarkis, J. Exploring sub-suppliers' compliance with corporate sustainability standards. J. Clean. Prod. 2016, 112, 1971-1984. [CrossRef]

85. Sartor, M.; Orzes, G.; Nassimbeni, G.; Jia, F.; Lamming, R. International purchasing offices in China: Roles and resource/capability requirements. Int. J. Oper. Prod. Manag. 2015, 35, 1125-1157. [CrossRef]

86. Sartor, M.; Orzes, G.; Nassimbeni, G.; Jia, F.; Lamming, R. International purchasing offices: Literature review and research directions. J. Purch. Supply Manag. 2014, 20, 1-17. [CrossRef]

87. Andrew Popp "Swamped in information but starved of data": Information and intermediaries in clothing supply chains. Supply Chain Manag. Int. J. 2000, 5, 151-161.

88. Jia, F.; Lamming, R.; Sartor, M.; Orzes, G.; Nassimbeni, G. International purchasing offices in China: A dynamic evolution model. Int. Bus. Rev. 2014, 23, 580-593. [CrossRef]

89. Zhang, C.; Viswanathan, S.; Henke, J.W., Jr. The boundary spanning capabilities of purchasing agents in buyer-supplier trust development. J. Oper. Manag. 2011, 29, 318-328. [CrossRef]

90. Eisenhardt, K.M.; Graebner, M.E. Theory Building from Cases: Opportunities and Challenges. Acad. Manag. J. 2007, 50, 25-32. [CrossRef]

91. Eisenhardt, K.M. Building Theories from Case Study Research. Acad. Manag. Rev. 1989, 14, 532-550.

92. Yin, R.K. Case Study Research: Design and Methods; SAGE: Thousand Oaks, CA, USA, 2009; ISBN 978-1-4129-6099-1.

93. Yin, R.K. Case Study Research: Design and Methods; Sage: Los Angeles, CA, USA, 2014; ISBN 978-1-4522-4256-9.

94. Hassini, E.; Surti, C.; Searcy, C. A literature review and a case study of sustainable supply chains with a focus on metrics. Int. J. Prod. Econ. 2012, 140, 69-82. [CrossRef]

95. Kotzab, H.; Westhaus, M. Research Methodologies in Supply Chain Management; Physica-Verlag: Heidelberg, Germany; New York, NY, USA, 2005; ISBN 978-3-7908-1583-2.

96. Ponelis, S.R. Using interpretive qualitative case studies for exploratory research in doctoral studies: A case of Information Systems research in small and medium enterprises. Int. J. Dr. Stud. 2015, 10, 535-550. [CrossRef]

97. Seuring, S.A. Assessing the rigor of case study research in supply chain management. Supply Chain Manag. Int. J. 2008, 13, 128-137. [CrossRef]

98. Amaratunga, D.; Baldry, D. Case study methodology as a means of theory building: Performance measurement in facilities management organisations. Work Study 2001, 50, 95-105. [CrossRef]

99. Seuring, S. Case study research in supply chains-An outline and three examples. In Research Methodologies in Supply Chain Management; Physica-Verlag HD: Heidelberg, Germany, 2005; pp. 235-250.

100. Voss, C.; Tsikriktsis, N.; Frohlich, M. Case research in operations management. Int. J. Oper. Prod. Manag. 2002, 22, 195-219. [CrossRef]

101. Woodside, A.G.; Wilson, E.J. Case study research methods for theory building. J. Bus. Ind. Mark. 2003, 18, 493-508. [CrossRef] 
102. Stuart, I.; McCutcheon, D.; Handfield, R.; McLachlin, R.; Samson, D. Effective case research in operations management: A process perspective. J. Oper. Manag. 2002, 20, 419-433. [CrossRef]

103. Koulikoff-Souviron, M.; Harrison, A. Using Case Study Methods in Researching Supply Chains. In Research Methodologies in Supply Chain Management; Physica-Verlag HD: Heidelberg, Germany, 2005; pp. 267-282. ISBN 978-3-7908-1583-2.

104. Almutairi, A.F.; Gardner, G.E.; McCarthy, A. Practical guidance for the use of a pattern-matching technique in case-study research: A case presentation. Nurs. Health Sci. 2014, 16, 239-244. [CrossRef] [PubMed]

105. Mayring, P. Qualitative Inhaltsanalyse: Grundlagen und Techniken; Beltz Pädagogik: Weinheim, Germany; Beltz: Basel, Switzerland, 2008; ISBN 978-3-407-25501-3.

106. Merriam, S.B. Qualitative Research: A Guide to Design and Implementation; Jossey-Bass: San Francisco, CA, USA, 2009; ISBN 978-0-470-28354-7.

107. Saunders, M.; Lewis, P.; Thornhill, A. Research Methods for Business Students; Always Learning: Harlow, UK; Pearson: Munich, ND, USA, 2012; ISBN 978-0-273-75075-8.

108. Cope, J. Researching entrepreneurship through phenomenological inquiry: Philosophical and methodological issues. Int. Small Bus. J. 2005, 23, 163-189. [CrossRef]

109. Duriau, V.J.; Reger, R.K.; Pfarrer, M.D. A Content Analysis of the Content Analysis Literature in Organization Studies: Research Themes, Data Sources, and Methodological Refinements. Organ. Res. Methods 2007, 10, 5-34. [CrossRef]

110. Stiles, W.B. Theory-building case studies of counselling and psychotherapy. Couns. Psychother. Res. 2007, 7, 122-127. [CrossRef]

111. Park-Poaps, H.; Rees, K. Stakeholder Forces of Socially Responsible Supply Chain Management Orientation. J. Bus. Ethics 2010, 92, 305-322. [CrossRef]

112. Apparelresources Trump's trade threats against China may help Vietnam I Trade News USA. Available online: https:/ / us.apparelresources.com/business-news/trade/trumps-trade-threats-against-china-mayhelp-vietnam/ (accessed on 23 January 2018).

113. Bloomberg The Top China-U.S. Trade Flashpoints. Bloomberg.com. 2017. Available online: https://www. bloomberg.com/news/articles/2017-03-06/china-u-s-trade-flashpoints-as-trump-s-team-prepares-its-case (accessed on 23 January 2018).

114. Turner, M. This is the "damage" imports have done to America's industries. Available online: http://www. businessinsider.de/this-is-the-damage-imports-have-done-to-americas-industries-2016-11 (accessed on 23 January 2018).

115. Knight, L.; Harland, C. Managing Supply Networks: Organizational Roles in Network Management. Eur. Manag. J. 2005, 23, 281-292. [CrossRef]

116. Harland, C.M.; Knight, L.A. Supply network strategy: Role and competence requirements. Int. J. Oper. Prod. Manag. 2001, 21, 476-489. [CrossRef]

117. Wu, Z.; Steward, M.D.; Hartley, J.L. Wearing many hats: Supply managers' behavioral complexity and its impact on supplier relationships. J. Bus. Res. 2010, 63, 817-823. [CrossRef]

118. Johnson, K.L.; Duxbury, L. The view from the field: A case study of the expatriate boundary-spanning role. J. World Bus. 2010, 45, 29-40. [CrossRef]

119. Hallenbeck, G.S.; Hautaluoma, J.E.; Bates, S.C. The benefits of multiple boundary spanning roles in purchasing. J. Supply Chain Manag. 1999, 35, 38-43. [CrossRef]

120. Krause, D.R.; Scannell, T.V.; Calantone, R.J. A Structural Analysis of the Effectiveness of Buying Firms' Strategies to Improve Supplier Performance. Decis. Sci. 2000, 31, 33-55. [CrossRef]

121. Vachon, S.; Klassen, R.D. Environmental management and manufacturing performance: The role of collaboration in the supply chain. Int. J. Prod. Econ. 2008, 111, 299-315. [CrossRef]

(C) 2018 by the authors. Licensee MDPI, Basel, Switzerland. This article is an open access article distributed under the terms and conditions of the Creative Commons Attribution (CC BY) license (http://creativecommons.org/licenses/by/4.0/). 